\title{
Nanoinformatics: a new area of research in nanomedicine
}

This article was published in the following Dove Press journal:

International Journal of Nanomedicine

23 July 2012

Number of times this article has been viewed

\section{Victor Maojo' \\ Martin Fritts ${ }^{2,3}$ \\ Diana de la Iglesia' \\ Raul E Cachau ${ }^{4}$ \\ Miguel Garcia-Remesal' \\ Joyce A Mitchell ${ }^{5}$ \\ Casimir Kulikowski ${ }^{6}$}

'Biomedical Informatics Group,

Departamento de Inteligencia

Artificial, Facultad de Informática,

Universidad Politécnica de

Madrid, Spain; ${ }^{2}$ SAIC-Frederick

Inc, National Cancer Institute at

Frederick, Frederick, Maryland,

${ }^{3}$ National Institute of Standards and

Technology, Gaithersburg, Maryland,

${ }^{4}$ Advanced Biomedical Computing

Center, National Cancer Institute,

SAIC-Frederick Inc, Frederick,

Maryland, ${ }^{5}$ Department of Biomedical Informatics, University of Utah, Utah,

${ }^{6}$ Department of Computer Science,

Rutgers, The State University

of New Jersey, New Jersey, USA
Correspondence: Victor Maojo Biomedical Informatics Group,

Departamento de Inteligencia Artificial, Faculdad de Informática, Universidad Politécnica de Madrid, Boadilla del Monte, 28660 Madrid, Spain

Tel +34913366897

Fax +34913524819

Email vmaojo@fi.upm.es

\begin{abstract}
Over a decade ago, nanotechnologists began research on applications of nanomaterials for medicine. This research has revealed a wide range of different challenges, as well as many opportunities. Some of these challenges are strongly related to informatics issues, dealing, for instance, with the management and integration of heterogeneous information, defining nomenclatures, taxonomies and classifications for various types of nanomaterials, and research on new modeling and simulation techniques for nanoparticles. Nanoinformatics has recently emerged in the USA and Europe to address these issues. In this paper, we present a review of nanoinformatics, describing its origins, the problems it addresses, areas of interest, and examples of current research initiatives and informatics resources. We suggest that nanoinformatics could accelerate research and development in nanomedicine, as has occurred in the past in other fields. For instance, biomedical informatics served as a fundamental catalyst for the Human Genome Project, and other genomic and-omics projects, as well as the translational efforts that link resulting molecular-level research to clinical problems and findings.
\end{abstract}

Keywords: biomedical informatics, nanomedicine, nanotoxicology, ontologies, electronic health records

\section{Introduction}

Recently, a consensus has begun to emerge about the informatics infrastructure needed to gather, curate, and share information among all the stakeholders in nanotechnology. A more effective nanoinformatics infrastructure should allow for efficient and extensive sharing of data, information, and knowledge about nanotechnology research and applications. In this review, we will initially focus on the medical applications of nanotechnology and their relationships to nanoinformatics. To avoid confusion with term usage, we use only the term "nanoinformatics" even though specific illustrative examples may be referenced in the literature under "bio-nanoinformatics" or "nanomedicine informatics." Finally, we will address other fields of application in nanotechnology with a discussion of the current directions and needs for developing a broader nanoinformatics infrastructure.

\section{Existing capability: biomedical informatics}

The use of computers in biomedicine began in the $1950 \mathrm{~s}$, with early applications in hospitals, ${ }^{1}$ and pioneering scientific computer programs for modeling the diagnostic process. ${ }^{2}$ Somewhat later, computational biology emerged to tackle problems of scientific inquiry at the molecular level. The field of medical informatics gradually developed, and came to include areas such as computerized medical records; artificial intelligence 
systems for medical diagnosis and planning; and laboratory, radiology, and hospital information systems. ${ }^{1}$ In computational biology, databases of macromolecular sequences, structures, and functions were developed and validated with experimental data. ${ }^{3}$ Later, the Human Genome Project (HGP) produced massive bioinformatics datasets, and the systems and software tools developed in the project were essential to the completion of the project ahead of schedule., ${ }^{4,5}$

Over the past decade, biomedical informatics (BMI) has continued to develop as a discipline encompassing both medical informatics and bioinformatics, ${ }^{6-8}$ based on a large number of research projects. These include over 1000 public databases containing -omics and disease information that are essential to biomedical translational research. ${ }^{9-14}$ The construction of ontologies such as Gene Ontology ${ }^{5}$ and many others $^{15-18}$ provided well-defined terminologies and semantic content for data, information, and knowledge sharing among heterogeneous systems.

Despite the broad scope of application of BMI, ranging from molecular medicine to public health, the field of nanomedicine ${ }^{19-21}$ has received scant attention. However, at the time of writing, almost 3000 references were retrieved in the PubMed database using the search term "nanomedicine." This number increases daily.

\section{Nanotechnology and nanoinformatics}

The many different challenges of nanotechnology for nanomedicine ${ }^{22,23}$ suggest the need for a new informatics area. In this biomedical context, nanoinformatics refers to "the use of informatics techniques for analyzing and processing information about the structure and physico-chemical characteristics of nanoparticles and nanomaterials, their interaction with their environments, and their applications for nanomedicine."24 The term was officially recognized after an initial workshop that took place in Arlington, VA, in 2007. ${ }^{25}$ This coincided with parallel activities launched at the same time in Europe with support from the European Commission. ${ }^{26}$

Nanoparticles roughly span the dimensions between 1 and $100 \mathrm{~nm}$. Below $1 \mathrm{~nm}$, their behavior can be explained by known atomic, molecular, and ionic interactions and forces; above roughly $100 \mathrm{~nm}$ their properties become similar to the bulk properties of the material. ${ }^{27-29}$ Inside that range, a particle can exhibit new and variable properties due to quantum effects. In addition, particles $<100 \mathrm{~nm}$ may also exhibit enhanced bioavailability and transport in and through biological organisms, tissues, cells, organelles, membranes, and interstices. ${ }^{30-32}$ Historically, particles within this range have been defined as "ultrafine" particles and have long been the subjects of research regarding their health - and toxic effects. ${ }^{31,32}$ Because new quantum effects or enhanced availability may also be evident as coating or layer thicknesses, surface variations, and/or pores fall into this size range, nanomaterials include larger materials that have nano-sized layer thicknesses or surface features. Finally, because the upper limit of the size range is somewhat arbitrary, other definitions are in use that extend the upper limit to $1000 \mathrm{~nm}-$ that is, to $1 \mu \mathrm{m}$.

Nanoparticles can be used as drug carriers and may alter a drug's reactivity, strength, and, ultimately, its behavior in vivo. ${ }^{33-35}$ Advances in nanotechnology design and delivery can allow delivery of a drug to a targeted tissue, release of a drug at a controlled rate, treatments for drug detoxification, ${ }^{36}$ or detection of the early stages of a carcinogenic process. ${ }^{37,38}$ For instance, Doxil ${ }^{\circledR}$ and Abraxane ${ }^{\circledR}$ are two nanodrugs already approved and currently available. ${ }^{33}$ The unique properties or "nano" characteristics of a nanomaterial including size, shape, charge, biocompatibility, solubility can be critical factors in enabling and facilitating important biofunctional goals like tumor penetration. ${ }^{39}$

Following Vélez and Vélez ${ }^{40}$ and Maojo et al, ${ }^{41}$ we consider five main areas in nanomedicine to provide some relevant examples of applications. These areas introduce significant informational challenges.

\section{Delivery systems}

Nanoparticles (eg, dendrimers, liposomes, buckyballs, fullerenes) can be designed as carriers to deliver genes, drugs, or molecules and to target specific parts of specific organisms (eg, organs, cells, molecules). By building detailed models and in silico computerized simulations, it is possible to design their structure and predict their properties. ${ }^{42}$ Delivery mechanisms include controlled release times, release rates, and detection systems to monitor effects of the drug or provide feedback. Nanodelivery - where nano-sized objects are transported through the body, target specific cells, and penetrate through cell and nuclear membranes - can improve the bioavailability, biocompatibility, therapeutic efficacy, stability, and solubility of drugs. ${ }^{43-46}$ Viruses, for example, are nano-sized and have evolved to perform exactly those same functions. ${ }^{47}$ We can differentiate between passive nanodelivery agents and those that can be triggered on arrival at the action site. Nanodelivery agents are designed to improve the availability of a poorly soluble or otherwise toxic bioactive compound (savaged drugs). To understand the value of nanodelivery devices in modern medicine, we should consider that an effective drug 
must satisfy many requirements, including being of low toxicity, being efficacious, specific, and soluble, before it can be considered a viable candidate for clinical trials. The staggering costs of developing a drug result from the need to satisfy all the requirements simultaneously. Recent estimates of the cost of designing a drug range between US\$3000 and 11,500 million. ${ }^{48}$ This constraint has resulted in the low number of primary drugs currently available. One of the best known examples of a nanodelivery agent is Abraxane ${ }^{\circledR}, 49$ a drug-polymer (albumin) blend that encapsulates paclitaxel in a polymer matrix that simultaneously increases the effective solubility of the paclitaxel while reducing the toxic effects of free paclitaxel. ${ }^{50}$

Nanodelivery agents are designed following a number of alternative chemical strategies, including covalent linking of bioactive drugs and homogeneous and heterogeneous encapsulation of the bioactive payload..$^{51}$ Nanodelivery devices can be designed (eg, controlling the device size) or decorated (eg, adding specific markers - such as folic acid - or antibodies) to target-specific sites. ${ }^{52}$ Sometimes, these targeted nanoparticles are combined with imaging agents that aid monitoring the evolution of the nanodevice in the patient's body. ${ }^{53}$ Nanodelivery devices combining multiple functionalities in a single scaffold are giving rise to a new generation of controllable platforms that can be activated using external sources (eg, laser heating). ${ }^{54}$ However, external triggering mechanisms have many limitations, including limited depth of penetration and possible side effects. Autonomous targeted nanodelivery agents (which could be understood as the simplest conceivable nanorobots) will take full advantage of a nanoplatform's technological capabilities by operating in deep tissues and even reporting the completion of the delivery process from within the site of action.

Nanoinformatics has a clear role in the scientific inquiry, design, and technological development of nanoparticle production. ${ }^{55}$ Similarly, it can be associated with the recording and analysis of experimental test results from the delivery of nanoparticles to different biomedical and ecological targets and contexts ${ }^{56}$ (eventually taking organism-microbiome interactions into account).

\section{Implantable devices}

Various types of nanodevices - nanorobots, for instance - can be designed for monitoring specific diseases. ${ }^{57-59}$ The field is still in its infancy, with existing prototypes showing proof of principle for targeted transport for biomedical applications. These devices can serve to mitigate toxicity by detecting modifications in biomedical parameters and releasing a drug under favorable conditions. The implantable device would require tailoring to a patient's individual response by monitoring, for example, information related to the patient's gene expression, proteome, and/or metabolome. ${ }^{41}$

\section{Diagnosis and prevention}

The interactions between nanoparticles and biological molecules in living organisms may have properties that make them particularly useful for diagnosing specific pathological conditions in certain diseases. For instance, luminescent nanoparticle quantum dots (QDs) can be engineered to bind to specific molecules, both in vitro and in vivo. The links between the in vitro and in vivo research can help in the diagnosis and therapy of major diseases ${ }^{47}$ such as cancer, cardiovascular diseases, respiratory diseases, and diabetes, as well as many other applications. Known biomarkers based on reported patient data can be correlated with disease pathology. This kind of decision support is an advanced area of research in BMI that can be extended very naturally to nanomedicine. ${ }^{20,39,60,61}$

\section{Therapeutics}

Nanotherapies can be less invasive than classical drug therapies and may require lower dosage levels. Improvements in efficacy can help reduce the side effects of many current drugs as nano-based clinical trials have demonstrated the benefits of nanotherapies and evaluated their toxicity relative to existing formulations. The authors have participated in related research for almost a decade, in testing the potential of clinico-genomic integration for designing models of clinical trials in the new context of genomic medicine. ${ }^{62}$ Computerized records, guidelines, and protocols must be designed for such nano-applications to integrate antimicrobial and antibacteriological information. Linked to both simulation and clinical trial results, these nanoinformatics applications could help identify and compensate for individual reactions to these pathogens and support the needed clinical guidelines. $^{24,41,63}$

\section{Materials}

Many nanomaterials are particles or designed structures, rather than biomolecules. Some properties that make these nanomaterials useful for biomedical applications include enhanced mechanical, optical, magnetic, and electrical characteristics. Analytical studies carried out to determine the biological interactions between specific nanoparticles and cell physiology should help in the design of new nanomedical approaches. ${ }^{64} \mathrm{New}$ biomaterials can also be used in implants for replacement therapy and in regenerative medicine. ${ }^{65}$ 
Information on early research in nanomedicine primarily consisted of journal publications, results of workshops and symposia, and reporting in the public media on these and other innovations and their benefits and risks. Later, a broader agenda for nanoinformatics evolved as the field progressed. Better characterization of nanomaterial structures, their physico-chemical properties, and their in vitro and in vivo interactions was necessary. ${ }^{66,67}$ For example, the US National Cancer Institute (NCI) established the Nanotechnology Characterization Laboratory as an integral part of its Cancer Nanotechnology Plan. It was evident that better instrumentation was needed in the laboratory, factory, and field for experiment, production process control, and separation techniques. This was due to the wide variability in their internal structures, surface ligand distributions, impurities, and transformational changes such as protein coatings.

New positive and negative controls were needed for existing standard analytical methods. Similarly, new methods were needed to standardize newly emerging sensing, delivery, release, and imaging modalities. Quantifying data reproducibility, uncertainty, and error of these new or modified methods would require ruggedness testing and sensitivity analysis of the methods. As the field evolved, a demand for reference and study materials grew, both for interlaboratory testing as well as for consistent studies of material transformation due to aging, handling, and contamination. In addition, it became evident that a nanomaterial registry was needed to provide unique identifiers for nanomaterials at the level of individual manufactured lots. The lot-to-lot property variations and libraries of well-characterized nanomaterials with controlled variations in their component structures were also needed to elucidate the correlation between the structures and their properties.

Finally, there was a need for an extensive, coordinated terminology for nanomaterials, their structures, and their properties. Such terminology would allow a more unambiguous interpretation of the accuracy and reliability of data developed by researchers in different disciplines and different material providers. The availability of standard materials and material libraries soon led to efforts to formulate quantitative structure-activity relationships for these materials. ${ }^{68}$ At the same time, more extensive modeling and simulation was needed to provide a detailed understanding of the mechanisms of efficacy and toxicity. Similarly, it required an improved understanding of nanomaterials production, modification, transformation, and disposal - which could be met only through multilevel modeling. An ultimate goal for this activity was improving data quality both for experiment and modeling and simulation. In parallel, this would lead to improve risk-assessment capability for the design of nanomaterial products and for evaluating their possible effects on the environment and human health and safety. ${ }^{66,67,69}$

\section{State of the art and present challenges}

The previous examples should be viewed from an informational perspective: is there a relevant role for informatics to support research, development, and translation in most of these nanomedical applications? Our answer is yes. Most of these examples included issues such as the development of large databases, device control, new biomedical imaging modalities, computerized decision support systems, the management and exchange of enormous amounts of heterogeneous data and knowledge, and/or creating models and simulators for characterizing nanoparticles and their efficacy and toxicity. Examples of nanomedical applications are now increasing rapidly in scientific publications such as the International Journal of Nanomedicine (which is nearing its first 1000 papers at the time of writing).

A major problem is that the science of nanomaterialbiological interactions is still at a very early stage. This means that we do not know yet how to engineer nanoparticles to minimize toxic effects in animals and on the environment. Modeling and simulation are essential here. Data mining of large databases of results from in vitro and in vivo experiments will be needed to help predict their possible side effects - as mentioned above. Nanoinformatics methods will be central to integrating many different methodologies involving discrete and continuous modeling, design, simulation, experimentation, visualization, and interpretation techniques. All this should improve our understanding of the risks presented by nanomaterials.

A systematic nomenclature for nanoparticle formulations and characterization is sorely needed for improving clarity and standardization in searching, locating, and comparing data on specific nanostructures within large preclinical and clinical databases. At the same time, the development of such a nomenclature would involve text mining of the complex scientific literature. Current approaches are based almost entirely on simple statistical associations among short segments of text. The use of novel, "visual" nano-ontologies could provide greater semantic content, together with research on more advanced methods of text mining from the literature. As mentioned, the choice of unique material identifiers is an important subtopic of ongoing research by the new Nanomaterials Registry supported jointly by the NCI, the National 
Institute of Environmental Health Sciences, and the National Institute of Biomedical Imaging and Bioengineering. ${ }^{70}$ The registry has developed a prototype database and user interface and initial datasets are being curated..$^{71}$ A related important issue is that of equivalency - that is, the determination of whether two nanomaterials are essentially the same.

In all the-omics fields, the need to transfer basic research from the lab to the bedside is a fundamental challenge. The American Medical Informatics Association sponsors the American Medical Informatics Association Summit on Translational Bioinformatics, which aims to translate the latest basic research results in the-omics areas into new knowledge for personalized medicine. ${ }^{72}$ We have also suggested a new subfield, which we called "translational nanoinformatics," 24 aimed at translating basic nano-level research into clinical applications. ${ }^{73}$ In this context, research results - and side effects, such as nanotoxicity, which is a major clinical concern - can help develop insights into how in vitro and model results can be transferred to clinical situations and practice.

To achieve such ambitious goals, professionals will need to draw on organized international networks of researchers, projects, and laboratories. These networks would enable people with related objectives to exchange data and resources and to establish collaborative initiatives. Broader and stronger collaborations between researchers worldwide will stimulate synergies that can accelerate research and help minimize nonproductive duplication of efforts (and possibly funding). Human and other genomic, proteomic, and metabolomic projects have provided telling examples of the advantages of openly sharing data and software resources. Such open strategies need to be considered, with appropriate adaptations for nanotechnology and nanomedicine - for instance, to accommodate proprietary issues associated with engineered nanoparticle design, production, and use.

\section{Challenges for informatics in nanomedicine}

As suggested previously, due to lack of information, the major research challenges and requirements include:

- new reference nanomaterials

- improved nanomaterial characterization as reported in the literature and in databases

- determination of the sensitivity of the analytical methods to variations in experiments, materials, and methodological approaches

- quantifying the error and uncertainty in the methods and protocols used to produce the data

- evaluation and management of various types of risks. ${ }^{74,75}$
One of the earliest papers (2004) using the term "nanoinformatics," had already pointed out some of the challenges that this area should address. ${ }^{76}$ Bioinformatics had evolved to solve problems related to data management in topics such as gel electrophoresis, amino acid sequencing, polymerase chain reaction, and gene mapping techniques. ${ }^{77}$ Meanwhile, nanoinformatics needed to address two main issues: (1) data results from nano-level experimentation, which lead to large and constantly changing sets of variables due to the continual growth of scientific knowledge; and (2) the need for control of the systems themselves. Further, the elements that the researcher aimed to manipulate dramatically increased the complexity of the research equipment itself and the refinement of the experiments. All of these required the processing and analysis of massive datasets, with complex calculations needed to manage computerized models at the atomic, molecular, and nano levels. The subsequent development of ever-increasing applications of nanotechnology and nanomedicine has uncovered many different problems that benefit from or require nanoinformatics techniques.

Various US agencies have already formulated recommendations for nanoinformatics. For instance, the Presidential Council of Advisors on Science and Technology provided a key recommendation in 2010 about nanoinformatics: "Support wide distribution and availability of new non-proprietary information about the properties of nanomaterials." ${ }^{78}$ Later, a group of scholars issued a roadmap identifying various challenges and proposing a research and development agenda. ${ }^{79}$ Similarly, the European Commission funded a support action called ACTION-Grid. ACTION-Grid, comprising groups of scholars from Europe, the USA, Latin America, and Africa, produced a white paper identifying the connections between BMI, grid computing, and nanoinformatics. ${ }^{80}$ Several of the authors of this paper participated in all three initiatives mentioned. A fourth document has been recently released entitled A Research Strategy for Environmental, Health, and Safety Aspects of Engineered Nanomaterials, by the Committee to Develop a Research Strategy for Environmental, Health, and Safety Aspects of Engineered Nanomaterials of the National Research Council. ${ }^{81}$

The main challenges proposed by the latter three of these groups $^{79-81}$ are shown in Table 1 .

Successful implementation of informatics strategies including ontologies, data sharing, and model developmentrequires appropriately annotated and curated datasets. As can be determined from these four reports, nanoinformatics, in contrast with the more developed field of bioinformatics, 
Table I Nanoinformatics challenges proposed by three recent initiatives

\begin{tabular}{|c|c|c|}
\hline Nanoinformatics 2020 Roadmap $(2010)^{79}$ & The ACTION-Grid White Paper $(2010)^{80}$ & $\begin{array}{l}\text { A Research Strategy for Environmental, } \\
\text { Health, and Safety Aspects of Engineered } \\
\text { Nanomaterials (2012) }\end{array}$ \\
\hline $\begin{array}{l}\text { Nanomaterial data gap workshops for discussing } \\
\text { how to facilitate the exchange of data and } \\
\text { information about engineered nanomaterials: } \\
\text { their physicochemical properties, behavior in } \\
\text { the environment, biological activity, etc }\end{array}$ & $\begin{array}{l}\text { Creation of a nanoinformatics infrastructure to } \\
\text { collect, curate, annotate, organize, and } \\
\text { archive the available data }\end{array}$ & $\begin{array}{l}\text { Identify minimum characterization principles } \\
\text { to develop standardized descriptors } \\
\text { (that is, metadata) for engineered } \\
\text { nanomaterials (ENMs) }\end{array}$ \\
\hline $\begin{array}{l}\text { Development of a meta-ontology for } \\
\text { nanoinformatics from existing ontologies } \\
\text { and structured databases, dealing with issues } \\
\text { such as interoperability and federation and } \\
\text { demonstrating its applicability across multiple } \\
\text { domains }\end{array}$ & $\begin{array}{l}\text { Design of extended web nano portals, linking } \\
\text { groups and information around the world to } \\
\text { facilitate data sharing }\end{array}$ & $\begin{array}{l}\text { Establish uniform metadata to describe ENM } \\
\text { manufacturing and distribution processes } \\
\text { and to correlate lot-to-lot variability of ENM } \\
\text { properties }\end{array}$ \\
\hline $\begin{array}{l}\text { Minimum information recommendations: } \\
\text { minimal information required for nanomaterial } \\
\text { characterization, quality assurance processes } \\
\text { for data collection and curation, ranking } \\
\text { system for quality and completeness of } \\
\text { data/datasets }\end{array}$ & $\begin{array}{l}\text { Development of repositories/databases of } \\
\text { use cases, resources, nanotoxicity data and, } \\
\text { clinical trial experiments or on nano facilitating } \\
\text { the reuse of data - such as } \\
\text { ArrayExpress for genomic data }\end{array}$ & $\begin{array}{l}\text { Develop ontologies and data formats to allow } \\
\text { relevant data on gene and protein expression } \\
\text { to be correlated with ENM toxicity mechanisms } \\
\text { and, in particular, to develop an ontology } \\
\text { "crawler" to aid in mapping relationships among } \\
\text { ontologies }\end{array}$ \\
\hline $\begin{array}{l}\text { A meta-crawler for searching nano-related } \\
\text { information on the Web, serving as an } \\
\text { interface to relevant ontologies (browse and } \\
\text { search), resources (semantic search), materials } \\
\text { (structural search), literature (links back to } \\
\text { relevant terminologies), and news }\end{array}$ & $\begin{array}{l}\text { Incorporation of regulatory aspects: } \\
\text { standards, issues related to open data } \\
\text { and source tools, quality control }\end{array}$ & $\begin{array}{l}\text { Develop strategies for federating } \\
\text { nanotechnology databases to allow seamless } \\
\text { data exposure and data sharing while } \\
\text { protecting intellectual property rights }\end{array}$ \\
\hline $\begin{array}{l}\text { Simulation challenge: development of simulation } \\
\text { and modeling tools for nanotechnology, } \\
\text { targeting specific materials and using standard } \\
\text { nanostructures that are well characterized to } \\
\text { compare and validate calculation tools }\end{array}$ & $\begin{array}{l}\text { Translational nanoinformatics: linking basic } \\
\text { research from the lab to the bedside and } \\
\text { nano-information to the Electronic } \\
\text { Health Record }\end{array}$ & $\begin{array}{l}\text { Develop new mechanisms for digital archiving } \\
\text { and annotating and updating of methods, data, } \\
\text { tools, and models to spur rapid and efficient } \\
\text { formation of new targeted national and } \\
\text { international scientific collaborations }\end{array}$ \\
\hline
\end{tabular}

raises some very special challenges. Biopolymers are often discrete structures or sequences, whereas nanomaterials typically exhibit a dispersion of sizes, compositions, and surface coatings. Such dispersions are difficult to define and reduce to the precise codes typically needed to classify and describe objects and their interactions in informatics modeling. Second, given the wide array of nanomaterial types and their as yet largely unknown interactions within different tissues and organismal physiologies, analytic measurements to make direct comparisons will be difficult to "anchor" to the appropriate experimental and clinical contexts. Informatics approaches will need to synthesize the information from multiple techniques to describe different nanomaterials. Such advances could help to overcome the many gaps in data and knowledge that describe nanomaterials in the literature, since most materials are as yet incompletely characterized.

It is worth noting the concurrence among the three different reports summarized in Table 1. This perspective is a significant acknowledgement that informatics technologies must become more central and more integrated with other scientific technologies and practices. ${ }^{82}$ This change may owe a great deal to the successful implementation of informatics in facilitating progress in genomics, proteomics, and metabolomics. The eventual goal of developing "intelligent" feedback processes - seen as a human-machine interaction that can incorporate learning from past experiments - among inquiry, design, testing, and refinement of bioparticles, can only be achieved with the intermediation of novel nanoinformatics techniques that include: modeling, a wide range of relevant simulations, and the sophisticated analysis and interpretation of massive experimental datasets. This objective goes beyond what is currently achieved with simple data mining, even in network science environments. ${ }^{24,81,83}$

In the next section, we comment on various areas that we consider the most challenging for nanoinformatics research.

\section{Nanoinformatics areas}

Over the last few years, the growing nanoinformatics community has begun to focus on an increasing number of research topics that could accelerate developments in nanomedicine. A nonexhaustive list of significant examples follows. 


\section{Data, ontologies, and exchanges of information}

The need to develop new data, information, and knowledge repositories, and create methods for information exchange in nanomedicine is growing rapidly. Developing biomedical ontologies, essential to the semantic web, is a current approach for facilitating data exchange through common terminological references.$^{84}$ Biomedical ontologies describe: concepts or classes - for instance, animals, organisms, organs, cells, molecules, proteins; their associated properties; semantic relationships and specific instances - elements, such as a specific cell or protein; and logical formalisms to interrelate the terms, properties, and instance relationships. Ontologies have been essential for managing and systematizing information and knowledge, particularly in the biomedical field. ${ }^{85}$ Ontologies are currently essential in facilitating system interoperability and information mapping, search, retrieval, extraction, and multilevel data integration. ${ }^{86}$

Two nano-related taxonomies or ontologies have already been reported: the Nanomedicine Taxonomy ${ }^{87}$ and the NanoParticle Ontology. ${ }^{88}$ In addition, there are proposals to develop domain ontologies, vocabularies, and taxonomies for topics such as cancer nanotechnology, with support from the NCI and other organizations. The NCI's white paper ${ }^{83}$ reports various initiatives, such as an ontology for new nanomaterials, an atlas of nanotechnology, and the Nanotech Index Ontology, among others.

The authors have carried out extensive research on system interoperability for biomedicine. These include syntactic and semantically focused approaches that use ontologies as conceptual references to overcome classical problems of database integration. ${ }^{89}$ The original focus in the last decade was on integration for-omics and systems biology research linked to clinical information, which can be adapted to address multilevel integration down to the nano level. There, it would need to include, for instance, the development of large repositories of nanoparticle information or new nanoontologies - both textual and visual, including information about the shapes and volumes of structures involved in nanolevel interactions. Various US research groups and laboratories have worked on related activities, such as the Cancer Biomedical Informatics Grid $\left(\mathrm{caBIG}^{\circledR}\right)^{90}$ and caNanolab (see Appendix). By way of example, Stokes et $\mathrm{a}^{11}$ developed an integrated information management system for personalized oncology, which is an "intelligent" information system for data management and interpretation that also supports the implementation of clinical applications.
As stated elsewhere, ${ }^{81,83}$ there is a significant need to develop an informatics portal with facilities analogous to those used in conjunction with the Protein Data Bank. Such a portal should focus on structural models of nanomaterials to be stored, described, curated, validated, and exchanged. In addition, predictive and probabilistic models and submodels could be made available to developers and users through this portal to complement new experimental techniques and theoretical approaches.

\section{Imaging}

QDs are semiconductor luminescent probes for many biomedical applications. ${ }^{92,93}$ Their various characteristics include small size (around $10 \mathrm{~nm}$ in diameter), high photostability, specific adjustable or selectable optical and electronic properties, size-tunable light emission, superior signal brightness, resistance to photobleaching, and broad absorption spectra for simultaneous excitation of multiple fluorescence colors and multimodality to facilitate in vivo diagnosis for example, for various types of cancer. ${ }^{21,92,93}$ They can be attached to targeted molecules within malignant tumors, facilitating early diagnosis and therapy, aimed at improving patient outcomes.

Along this line of research, many other materials are entering clinical trial. ${ }^{94}$ Lanza et $\mathrm{al}^{95}$ have developed a nanoparticle magnetic-resonance-imaging contrast agent that binds to blood vessels appearing with early tumor development. In vivo molecular imaging capabilities will enable optical biopsies, with tumors being typed and staged at the time of detection. ${ }^{95,96}$ More complete molecular characterization of lesions can enable physicians to recognize and prevent chemoresistance. Advanced imaging combined with traditional surgical techniques for intraoperative guidance will make improved resections of cancerous tumors possible. ${ }^{39}$

Similarly, targeted gold nanoparticles can improve molecular computed-tomography (CT) imaging of cancer. ${ }^{97}$ Various reports ${ }^{97,98}$ have suggested the feasibility of cancer diagnosis in vivo by using molecular markers rather than anatomical structures, through better visualization by clinical CT. With nanoparticles, CT can go beyond its present structural imaging capabilities by adding functional and molecular-based imaging capacities as well. For instance, various types of nanoprobes have been developed as blood pool CT contrast agents, such as gold nanoprobes and nanotags, iodine-based emulsions, and tantalum oxide nanoparticles. ${ }^{97}$

Imaging techniques based on nanotechnological research would be less invasive and more precise than existing 
methods in biomedical imaging. For example, QDs generate signals of long duration that can be used to improve image quality. Advanced informatics methods could then link tissue banks with images of tissues and histology results to provide enhanced image annotation down to the nano level. The images could also be linked to electronic health records as needed.

\section{Modeling}

Molecular modeling and simulation techniques are central to systems biology research. In the nano world, they will be the key to the bridging of nano-level effects with aggregated, molecular, cellular, tissue, organ, and organismal system level effects. Quantum mechanics, molecular modeling, and simulation techniques provide the scientific basis for analyzing and understanding the basic physical, chemical, and biological properties of nanoparticles and nanomaterials. ${ }^{99}$ Their results provide new insights about their specific interactions with biological systems. Computer-intensive methods like hybrid quantum mechanic and molecular dynamic simulations facilitate the characterization of nanoparticle properties. This also provides substantial information about biological phenomena related to the interactions between nanoparticles and physiological systems, ${ }^{100}$ exploring interactions at different scales. Through these simulations, one can study the fundamental physico-chemical properties of nanoparticles. High-performance computing infrastructures - such as grid, cloud computing, or dedicated supercomputers - can help accelerate this work.

Bewick et al $^{101}$ have reported on the complexity arising from the inherent characteristics of natural biological systems. These include their heterogeneity, their multiscale space-time interactions, the noise generated in physical systems at the nanoscale, the strong coupling between processes that occur at different scales, and the challenging dimensionality size of data needed to represent typical biological systems. ${ }^{101}$

Jaramillo-Botoro et $\mathrm{al}^{102}$ have suggested the typical components of a nanomedical model in terms of a five-level theoretical hierarchy: (1) quantum mechanics to determine electronic states, (2) force fields that result from averaging the electronic states and thereby obtaining atom-based forces, (3) simulations of atomic interactions based on force fields, (4) mesoscale or course-grained descriptions that average over many atoms, and (5) continuum mechanics using distributed properties for membranes, cells, tissues, and organs.

As in other biomedical and engineering areas, if insufficient complexity is assumed, the descriptions will not be adequate or accurate for representing the phenomena. However, if too much complexity is assumed, mathematical models may prove too complex to be useful from a practical perspective. According to Bewick et al, ${ }^{101}$ the challenges for nanobiosystem modeling are twofold. First, we must develop improved techniques for dealing with nanoscale biological complexity from a computational perspective. Second, we need to understand the role of biophysical and chemical complexity itself in nanobiosystem behavior. ${ }^{103}$

In this regard, there is no Protein Data Bank-like entity to develop, validate, and curate nanoparticle or nanomaterial structures - except the Collaboratory for Structural Nanobiology. ${ }^{104}$ This modeling cannot be done without several different layers of structural modeling. It is not possible to discover structure-property relations unless we already know the structural motifs of interest, for which researchers need to build enough knowledge across different platforms. Thus, modeling must be linked to what we have mentioned already regarding the need to establish networks of researchers. The latter can collaborate by sharing both structural and predictive models, which will be essential to accelerate research and translation to clinical practice. ${ }^{81}$

\section{Data and text mining for nanomedical research}

Over the past decade, the authors have carried out an extensive examination of text mining research, particularly for bioinformatics problems. ${ }^{105-107}$ We later discuss some examples of the authors' research in this area.

Using data mining approaches, researchers try to extract, confirm, or discover new knowledge from large databases. Data mining was traditionally used in large medical and biological databases to generate or confirm research hypotheses. Their application has been fundamental for extracting knowledge patterns - for example, decision trees or association rules - either for descriptive or predictive tasks. Most of these tasks are based on inductive approaches. In the context of nanobiology, for instance, it is possible to use various mining strategies for predicting the potential effects of engineered nanomaterials (ENMs) based on their chemical properties, their mechanisms of action and the biological pathways involved. This requires standardized data collection and warehousing of very diverse sets of data and metadata types and formats. ${ }^{81}$ This means that adequate informatics infrastructure will be essential to facilitate storage and data sharing of multilevel data related to research, development, translation, and regulation. 
From a public health perspective, biostatisticians and epidemiologists can monitor the impact of nanomedical applications by carrying out surveillance studies of nanoenabled drugs to monitor their potential toxicity as well as effectiveness in clinical practice. ${ }^{46,60}$ In the era of personalized medicine - usually referred to as "genomic medicine," even though nanomedicine is already transforming this characterization - professionals and researchers must study and assess the use of nanomedical treatments for specific patients, based on individual features.

\section{Clinical trials and toxicity}

Nanomedicine will require new approaches to medical care and clinical trials, which are focused on testing their efficacy but weigh the potentially deleterious side effects of nanoparticles. ${ }^{94,108-110} \mathrm{As} \mathrm{Lai}^{110}$ and Adiseshaiah et $\mathrm{al}^{111}$ have suggested, the potential hazards of nanomaterials must be evaluated by conducting in vitro high-throughput assays and mechanistic studies and comparing the data obtained from the latter with available reference data. Hazard identification of nanoparticles and their effect on humans has been conducted for several ENMs using in vitro and in vivo methods. ${ }^{112}$ Complementary research on the toxicity of nanomaterials and its impact on environment research can be also carried out, focusing on understanding toxicity mechanisms of ENMs. Additional information is needed to analyze the pathways of biochemical responses to ENMs and how to obtain data from adverse outcomes.

Important factors influencing nanotoxicity are size, shape, particle surface, biopersistence, surface chemistry, chemical components, dosage, free-radical production, and release of toxic ions through dissolution in biological media. ${ }^{108,110}$ Nanoparticles can also interact with the immune system, provoking other side effects in humans. ${ }^{113}$

All these analyses will produce datasets that can inform the design and construction of computational models and simulations that will attempt to predict the toxicity of nanoparticles. Nanoinformatics must help to design and implement predictive models characterizing the interactions involved in nanoparticle exposure, the aggregate and cumulative hazards, and the health and environmental risks on various tissues and body organs and systems. Data must be coherently organized, shared, and integrated to allow effective data mining and to explain observed patterns of nanotoxicity. In the section entitled Examples of applications, we provide research examples of how nanoinformatics and nanotoxicity can be related.
For nanomedicine to become practical, toxicity information must be available to physicians and included in computerized medical records. There are public databases of toxic effects such as the Nanoparticle Information Library (http:// nanoparticlelibrary.net/index.asp) created by the National Institute for Occupational Safety and Health and administered by the Oregon Nanoscience and Microtechnologies Institute (ONAMI), and the Nanomaterial-Biological Interactions (NBI) Knowledgebase (http://nbi.oregonstate.edu/analysis. php) hosted by ONAMI.

\section{Standards}

For BMI, a large number of standardized nomenclatures, vocabularies, coding standards and terminologies, such as the Health Level Seven International, Logical Observation Identifiers Names and Codes, Systematized Nomenclature of Medicine, Digital Imaging and Communications in Medicine, and the tenth revision of the International Classification of Diseases, need to be extended to add concepts and links to nano-related information. The Unified Medical Language System, produced by the US National Library of Medicine is set to incorporate biological vocabularies and ontologies like Gene Ontology ${ }^{5}$ - to link clinical- with molecular-level information. To this could be added nanomedical concepts and links that expand the current scope of biomedicine towards the nano level. For instance, nanomaterials require similar types of naming conventions - common and systematic names, computable representations of structures or open-source Chemical Abstracts Service registry numberlike codes-for linking data from many sources. ${ }^{108}$

Nanotechnological research and development requires a comprehensive development pipeline from nanoparticle synthesis to characterization, including in vitro and in vivo empirical approaches. This leads to clinical applications of all the materials and processes involved. For such a substantial requirement, nanoinformaticians must design and develop methods and build software tools to access, share, and integrate a large amount of disparate information. As mentioned by Baker et al, ${ }^{83}$ the integration of these data, methods, and knowledge is likely to become a central challenge for nanoinformatics. For this, the prior experience of similar challenges in BMI may prove very helpful.

An example of such building upon existing biomedical systems for nanoinformatics is the Investigation, Study, Assay (ISA)-Tab file format, ${ }^{114}$ which shares common "Investigation" (the project context), "Study" (a unit of research), and "Assay" (analytical measurement) metadata categories. The extensible, hierarchical structure of this format enables 
the representation of studies employing one or a combination of technologies, focusing on the description of its experimental metadata (ie, sample characteristics, technology and measurement types, sample-data relationships). ISATab standards and their extension to the nano level in ISA-TAB-Nano will allow the same standard formats for high-throughput screening, nanomaterial characterization data (physico-chemical, in vitro, and in vivo) and, possibly, in silico data as well.

Another significant example involves the development of standards for the minimum information required to characterize nanomaterials ${ }^{115}$ - which extend previous efforts carried out for microarrays - and for harmonization of formats for data sharing.

\section{Impact}

The amount of information on nanoparticle toxicity is increasing, suggesting that a wide range of characteristics may mediate and determine the scale, dynamics, and health and environmental impact of adverse effects - and of current therapeutics. Initial results, from both animal studies and in vitro experiments, suggest that the type, size, and mode of utilization of nanoparticles may produce different effects on cell cultures. ${ }^{116}$ Understanding the toxicity mechanisms and effects of nanoscale materials - nanotoxicology - is the most critical problem now faced by nanomedical technology. The need for managing this information and linking it with specific patient data follows directly. There are various nanoscale materials for biological application that have failed because of their toxicity. ${ }^{45,109,110}$ This failure is due to the complexity of living organisms, which makes it difficult to predict the consequences (ie, adverse reactions) of inserting a material into biological systems: the toxicity of some nanomaterials involves very complex pathways as well as specific interactions between biological tissues and synthetic materials and the transformations those materials may undergo. All these issues point to the need for diverse informatics methods and tools to augment basic research results and bring together information from all relevant lines of research and clinical tests. Annotating the literature presents considerable challenges both in theory and in practice. For instance, to alert researchers as to whether a particular nanomaterial has been sufficiently characterized, whether the methods used to characterize the nanomaterial and its interactions were validated, whether the models used were appropriate, or whether invalid conclusions might have been drawn. As mentioned, we are carrying out research on some of these issues.
We summarize different aspects of nanoinformatics and its relevance to international research in Figure 1. In this figure, the various areas on which nanoinformatics can have a tremendous impact in the future are shown. We have classified these potential impact areas into eight categories: (1) industrial, (2) economic, (3) international collaboration, (4) national policy, (5) informatics, (6) societal, (7) educational, and (8) scientific. For expanded information on these topics, The ACTION-Grid White Paper is publicly available. ${ }^{80}$

A pervasive nanoinformatics problem is poor quality of available data, especially in terms of its reliability and reproducibility. This is due to various reasons, including:

- the lack of development and utilization of validated methods for characterization of the nanomaterials and their properties

- the incomplete characterization of nanomaterials and the lack of reference material to be used in the assays; the lack of curation and annotation of available data so that a measure of its reliability can be provided

- the need for training materials for standard assays; the rise of multiple silos for nanotech data

- the problems in federating those silos into a searchable system

- the integration with -omics and system biology data

- and the need for a set of ontologies that allows mapping and navigation among different ontologies for different disciplines through a harmonized system of concept definitions.

A key issue is that nanoinformatics should not be just a support technology but a fundamental approach to integrating the various areas of research and translation needed for the field within a reasonable time. The diverse nano products cannot succeed without better characterization, validated methods, better training, and informatics systems that permit practitioners to cope with the massively large amount of information needed to properly utilize the technology. This is an urgent need. How will a practicing physician cope with all the different tests, treatment options, massively complex diagnosis decision aids, and so on, without informatics systems? Nanotechnology offers the hope of developing and testing these systems now so that we develop flexible methods of expanding them as our knowledge grows. Finally, researchers, designers, clinicians, practitioners, information brokers, and regulators face a critical issue of coping with a myriad of large information sources, for which nanoinformatics methods and tools are absolutely necessary. On balance, the persistence of problems within the entire scientific community should also 


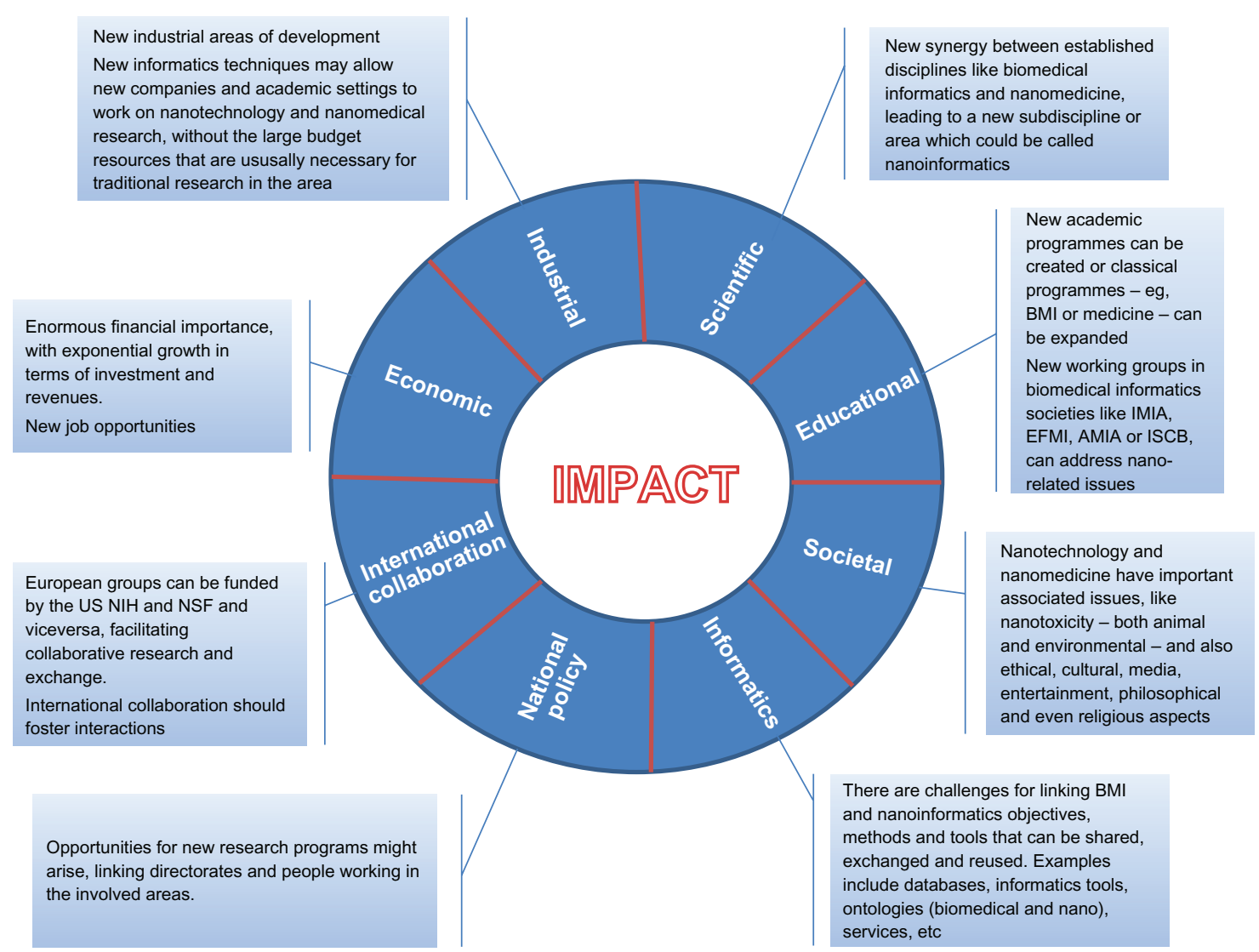

Figure I Impact of nanoinformatics in different topics, modified from an earlier version presented by the authors in The ACTION-Grid White Paper. ${ }^{80}$

Abbreviations: AMIA, American Medical Informatics Association; BMI, biomedical informatics; EFMI, European Federation for Medical Informatics; IMIA, International Medical Informatics Association; ISCB, International Society for Computational Biology; NSF, National Science Foundation; US NIH, National Institutes of Health.

be considered - as discussed in a December 2011 special issue of the journal Science on data reproducibility. ${ }^{117}$ In this sense, nanoinformatics could be a demonstration of how to enhance data and model reproducibility in other scientific fields.

It is yet unknown whether the cost of research and development in nanomedicine will significantly increase the cost of biomedical research. In this regard, some positive effects can be anticipated. For instance, nanoparticles could rescue or save from neglect failed or inappropriate drugs for which most of the biomedical research has already been done or they could be used for regenerative medicine. ${ }^{83}$ Similarly, the scientific and technological opportunities for BMI-nanoinformatics interactions are many.

Educational and ethical aspects of nanomedicine will be a key issue for nanoinformatics, too. Nanotechnologists are often people with backgrounds in chemistry, physics, and engineering. For nanoinformatics (and nanomedicine), people with expertise in informatics, medicine, biology, pharmacy, and other fields will be necessary. Future programs and degrees in nanomedicine - and nanoinformatics - will have to incorporate a much broader range of research to address the multidisciplinary types of questions involved. Finally, nanoinformaticians - in analogy to what has been proposed for biomedical informaticians by scholars such as Mark Musen - will have to act as "information brokers," 118 connecting people with different scientific backgrounds and interests.

\section{Ethical issues}

Nanotechnology and nanomedicine present important ethical issues, such as nanotoxicity, in terms of the organisms and the environment they try to control. ${ }^{119}$ A recent review concludes that none of the ethical questions surrounding nanomedicine are new or unique and that they would hold true for any new medical device or medicine that is being evaluated. ${ }^{74}$ The shift to nanomedicine creates a significant increase in technology use, which might change current clinical practice. On the contrary, Sandler ${ }^{75}$ argues that nanomedicine is more closely linked to ethics than to risks, since it raises a broad range of unique ethical issues. These issues will have also an affect on public health. ${ }^{60,120}$ 


\section{Examples of applications}

If we search for the term "nanoinformatics" in PubMed, only a few references are available at the time of writing - and most by the authors themselves. There are several reasons for such a result. First, the term "nanoinformatics" is quite new, and its use is slowly expanding. Second, many computer applications have been developed for nanotechnological and nanomedical applications, but they have not been listed or published under the umbrella of the term "nanoinformatics." Finally, the concept of nanoinformatics as an interdisciplinary field, with research and results that can lead to advancing the scientific basis of nanomedicine and its developments, has not yet been widely adopted. That is, nanoinformatics has not yet been recognized as a field in which original and independent work can be carried out.
In this section, we give some examples that fully conform to "nanoinformatics" as characterized in this paper. They are related to information retrieval, text mining for locating nanotoxicity information in the literature, and visual ontologies.

\section{Information retrieval}

We have recently developed an automated text indexing and retrieval engine that links scientific articles to concepts from the NanoParticle Ontology ${ }^{88}$ and the Foundational Model of Anatomy. ${ }^{121}$ The indexing engine was built following a dictionary-based approach, similar to that adopted by Garten and Altman. ${ }^{122}$ With the search engine, users can search for papers reporting which nanoparticles are more suitable for delivering a certain drug to a given anatomical location, or for identifying which nanoparticles are toxic to a specific

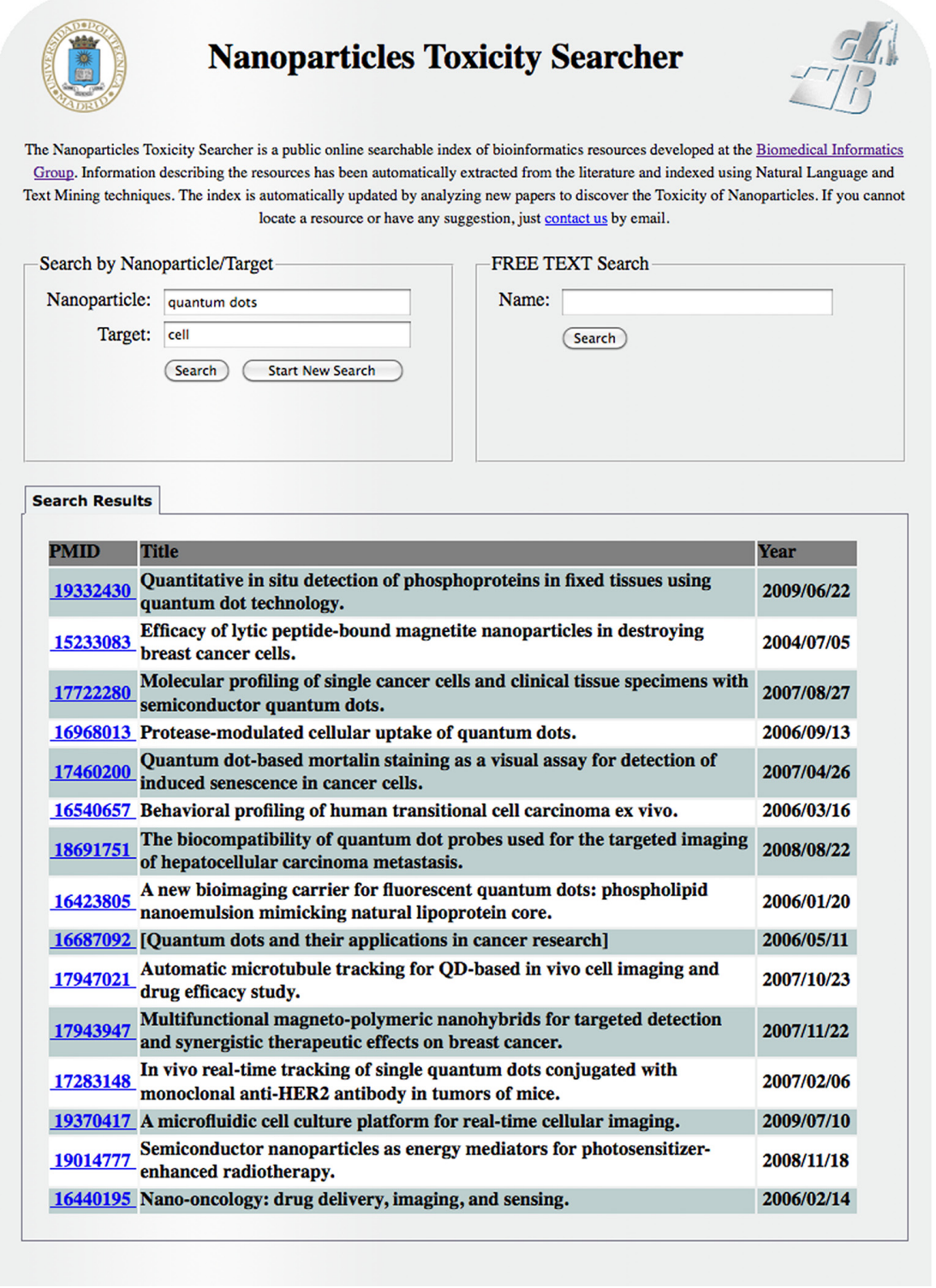

Figure 2 Screenshot of the Nanoparticles Toxicity Searcher, using "quantum dots" as an example. 
Table 2 Important events in the nanoinformatics field over the past 5 years

\begin{tabular}{|c|c|}
\hline Nanoinformatics events and activities & Date \\
\hline \multicolumn{2}{|l|}{ Past } \\
\hline Launch of the first version of the caNanoLab Portal, a research framework for biomedical nanotechnology data sharing. & March 2007 \\
\hline \multicolumn{2}{|l|}{ National Cancer Institute } \\
\hline Nanoinformatics Workshop. Arlington, VA & June 2007 \\
\hline Launch of NanoMedNet, a platform for education and training in nanomedicine for medical professionals & August 2007 \\
\hline The Network for Computational Nanotechnology receive a grant of USD $\$ 18.25$ million from the National Science & September 2007 \\
\hline \multicolumn{2}{|l|}{ Foundation to support the nanoHub project, focused on computer simulation at the nano level } \\
\hline Establishment of NanoSafe Inc, Virginia Tech Corporate Research Center's KnowledgeWorks Business Accelerator & October, 2007 \\
\hline Research Challenges for Nanomanufacturing Systems. Arlington, VA & February 2008 \\
\hline Launch of NanolmpactNet, a multidisciplinary European network on the health and environmental impact of nanomaterials & April 2008 \\
\hline Launch of ACTION-Grid, first European initiative on Nanoinformatics & June 2008 \\
\hline \multicolumn{2}{|l|}{ NSTI Nanotech Conference organized by Nano Science and Technology Institute (NSTI). Boston, MA } \\
\hline Launch of the International Alliance for NanoEHS Harmonization at Nanotox 2008 Conference. Zurich, Switzerland & September 2008 \\
\hline Launch of the first working version of the NanoParticle Ontology. NCl Cancer Biomedical Informatics Grid (caBIG ${ }^{\circledR}$ ) & December 2008 \\
\hline \multicolumn{2}{|l|}{ Nanotechnology Working Group } \\
\hline Publication of the white paper Ontologies in cancer nanotechnology research. caBIG, National Cancer Institute & January 2009 \\
\hline $\begin{array}{l}\text { Publication of the white paper The need for minimum information standards for development and advancement of } \\
\text { nanomaterials as cancer diagnostics and therapeutics. caBIG, National Cancer Institute }\end{array}$ & February 2009 \\
\hline \multicolumn{2}{|l|}{ Publication of the white paper Nanotechnology Informatics White Paper.$^{83} \mathrm{caBIG}$, National Cancer Institute } \\
\hline Nanotech Conference and Expo 2009 organized by NSTI. Houston, TX & May 2009 \\
\hline \multicolumn{2}{|l|}{ ID Heterostructure Tool, new tool for the simulation of heterostructures at the atomic scale } \\
\hline $\begin{array}{l}\text { Launch of GoodNanoGuide, an Internet-based collaboration platform about handling nanomaterials in an occupational } \\
\text { setting. International Council on Nanotechnology (ICON) }\end{array}$ & June 2009 \\
\hline Inclusion of Medical Nanoinformatics in the "Recommendations of the International Medical Informatics Association (IMIA) & January 2010 \\
\hline \multicolumn{2}{|l|}{ on Education in Biomedical and Health Informatics" } \\
\hline \multicolumn{2}{|l|}{ Synergies in Nanoscale Manufacturing and Research Workshop. Ithaca, NY } \\
\hline Report to the President and Congress on the Third Assessment of the National Nanotechnology Initiative. President's & March 2010 \\
\hline \multicolumn{2}{|l|}{ Council of Advisors on Science and Technology $(P C A S T)^{78}$} \\
\hline Nanoinformatics publication in Pediatrics Research (first in a medical journal) by Maojo et al "Nanoinformatics and & May 2010 \\
\hline \multicolumn{2}{|l|}{ DNA-based computing: catalyzing nanomedicine"24 } \\
\hline \multicolumn{2}{|l|}{$\begin{array}{l}\text { Development of nano-TAB as ASTM standard (ASTM WK28974) initiated, standard for identifying nanomaterials and } \\
\text { characterizations in a tab-delimited format }\end{array}$} \\
\hline NanoTech Conference and Expo 2010. Anaheim, CA & June 2010 \\
\hline \multicolumn{2}{|l|}{ Launch of the Collaboratory for Structural Nanobiology. National Cancer Institute and University of Talca } \\
\hline Publication of the National Nanotechnology Initiative Signature Initiative: Nanoelectronics for 2020 and Beyond & July 2010 \\
\hline $\begin{array}{l}\text { Publication of The ACTION-Grid White Paper on Nanoinformatics. }{ }^{80} \text { ACTION-Grid Consortium, } \\
\text { approved by the European Commission }\end{array}$ & September 2010 \\
\hline \multicolumn{2}{|l|}{ Destination Nano! Premier nanomanufacturing Conference, UMass Lowell. Lowell, MA } \\
\hline \multicolumn{2}{|l|}{ Launch of the Nanoscience Portal. National Science Foundation } \\
\hline \multicolumn{2}{|l|}{ "Nanoinformatics: making sense out of nanotechnology information.” International Council on Nanotechnology } \\
\hline \multicolumn{2}{|l|}{ Publication of the report Nanotechnology Research Directions for Societal Needs in 2020. National Science Foundation } \\
\hline 5th General Assembly and Annual Forum of the European Technology Platform on Nanomedicine. Milan, Italy & October 2010 \\
\hline \multicolumn{2}{|l|}{ Nanoinformatics 2010. Arlington, VA } \\
\hline \multicolumn{2}{|l|}{ nanoinformatics research applied to nanomedicine" } \\
\hline Nanotechnology Innovation Summit, Washington DC. National Nanotechnology Initiative & December 2010 \\
\hline Establishment of QNano, integrated hub to support Europe's nanosafety research community & February 2011 \\
\hline \multicolumn{2}{|l|}{ Publication of the National Nanotechnology Initiative Strategic Plan. National Science and Technology Council } \\
\hline Publication of the Nanoinformatics 2020 Roadmap. ${ }^{79}$ National Nanomanufacturing Network & April 20II \\
\hline 5th Concertation and Consultation Workshop on Micro-Nano-Bio-Convergence Systems 20II. Mondragon, Spain & \\
\hline Nanoinformatics publication in Biological Research by González-Nilo et al, "Nanoinformatics: an emerging area & May $201 \mathrm{I}$ \\
\hline of information technology at the intersection of bioinformatics, computational chemistry and nanobiotechnology" & \\
\hline Publication of the Materials Genome Initiative Report Materials Genome Initiative for Global Competitiveness. & June $201 \mathrm{I}$ \\
\hline National Sciences and Technology Council, Washington DC & \\
\hline NanoTech Conference and Expo 20II. Boston, MA & \\
\hline $\begin{array}{l}\text { Nanoinformatics publication in Wiley Interdisciplinary Reviews, Nanomedicine and Nanobiotechnology by Thomas et al, } \\
\text { "Informatics and standards for nanomedicine technology"70 }\end{array}$ & October 20II \\
\hline
\end{tabular}


Table 2 (Continued)

\begin{tabular}{|c|c|}
\hline Nanoinformatics events and activities & Date \\
\hline Final specification of the nano-TAB standard & November 20II \\
\hline Nanoinformatics 20II, Arlington, VA & December 20II \\
\hline A Research Strategy for Environmental, Health, and Safety Aspects of Engineered Nanomaterials released. ${ }^{81}$ & January 2012 \\
\hline \multicolumn{2}{|l|}{ National Research Council } \\
\hline \multicolumn{2}{|l|}{ Launch of the ISA-TAB-Nano (first version), general purpose framework that provides a standard means to } \\
\hline \multicolumn{2}{|l|}{ communicate data on nanomaterial properties and experiments. Nano Working Group, National Cancer Institute } \\
\hline European Summit for Clinical Nanomedicine 2012. Basel, Switzerland & April 2012 \\
\hline \multicolumn{2}{|l|}{ Future events } \\
\hline 6th Concertation and Consultation Workshop on Micro-Nano-Bio-Convergence Systems 2012. & May 2012 \\
\hline \multicolumn{2}{|l|}{ Athens, Greece. European Commission } \\
\hline Nanofair 2012 - 9th International Nanotechnology Symposium. Dresden, Germany & June 2012 \\
\hline \multicolumn{2}{|l|}{ 8th NanoBio-Europe conference. Varese, Italy } \\
\hline \multicolumn{2}{|l|}{ NanoTech Conference and Expo 20I2. Santa Clara, CA } \\
\hline 9th International Conference on Nanosciences and Nanotechnologies (NNI2). Thessaloniki, Greece & July 2012 \\
\hline \multicolumn{2}{|l|}{ International Conference on Nanoscience + Technology (ICN+T20I2). Paris, France } \\
\hline Nanoinformatics 2012 & To be determined \\
\hline
\end{tabular}

anatomical structure. Figure 2 shows a screenshot of the prototype of this engine, the Nanoparticles Toxicity Searcher, that we have developed. If the user is interested in discovering the toxic effects of QDs in cells as reported in the literature, they would type the keywords "quantum dots" and "cell" in the boxes labeled "Nanoparticle" and "Target." Then, they would click the "Search" button, and the system would automatically retrieve all papers indexed by these keywords, as shown in the figure. The abstract and/or the full text of the articles can then be easily retrieved by clicking their corresponding PubMed identifiers or PMID hyperlinks, as shown.

Second, we have automated the recognition and extraction of mentions of nanotoxicology-related entities from the scientific literature. The targeted entities belong to four different categories: nanoparticles, routes of exposure, toxic effects, and potential targets. The entity recognizer was trained using a text corpus that we specifically created for this purpose and was validated by two nanomedicine/ nanotoxicology experts. The text corpus is composed of around 300 sentences manually extracted from papers available and indexed in PubMed, which were annotated with relevant nanotoxicology entities. This kind of research can serve as a basis to stimulate further research on information retrieval and text mining - for example, for nanotoxicological purposes - as has occurred in areas such as BMI.

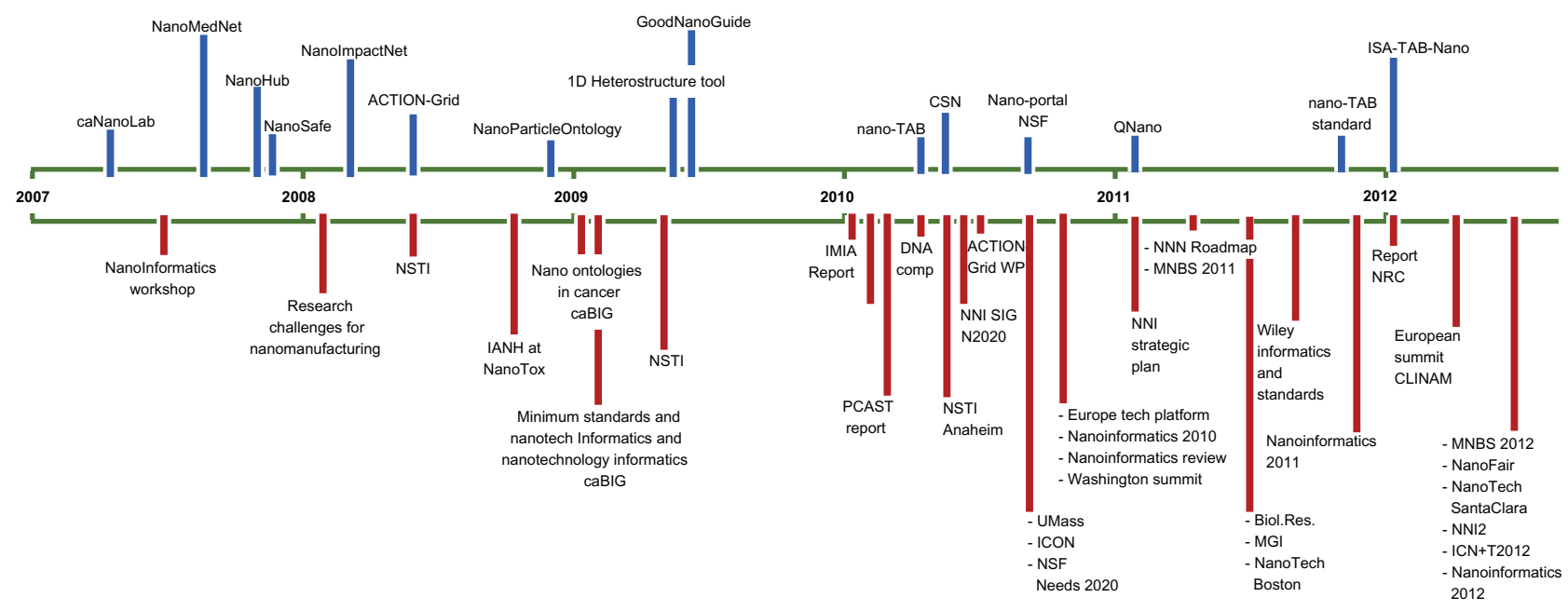

Figure 3 Timeline of events and activities depicted in Table 2.

Abbreviations: Biol Res, Biological Research; CSN, Collaboratory for Structural Nanobiology; IANH, International Alliance for NanoEHS Harmonization; ICON, International Council on Nanotechnology; ICN, International Conference on Nanoscience; MNBS, Micro-Nano-Bio Systems; NNI, National Nanotechnology Initiative; NNN, National Nanomanufacturing Network; NRC, National Research Council; NSTI, Nano Science and Technology Institute; NSF, National Science Foundation; PCAST, President's Council of Advisors on Science and Technology. 
These two projects can be viewed as early results supporting our claims regarding the usefulness of nanoinformatics efforts in indexing resources about nanotoxicity using information available from the literature. However, even if it were possible to automatically generate a database of toxic effects from current data, this would provide no annotation regarding data reliability or reproducibility. Future efforts combining this kind of data with others derived from interlaboratory studies, as well as robust techniques for analysis of data for method development and validation efforts, are needed to help make sense of the data that can be aggregated. Similarly, data curation will require wikis or other means to integrate and assess comment on search results, to help improve methods, models and techniques, and to demonstrate the utility, effectiveness, advantages, and risks of the enterprise. For such purposes, international collaborations among researchers with complementary expertise will be crucial.

\section{Visual ontologies}

Particle shape and design are fundamental in determining the characteristics of the biological and biophysical processes that involve them. There are reports of the influence of nanoparticle shape and design on their interaction with target tissues and of these characteristics involving altered biodistribution, cellular internalization, and trafficking, among other processes. ${ }^{46}$ In nanomedicine, the effect of particle shapes on these processes might play a significant role in future applications of nanoparticles for drug delivery. We have carried out original research centered on the recognition of nanoparticle shape and its classification by means of new types of visual ontologies/taxonomies for shapes and structures. ${ }^{123}$ There are two subobjectives:

1. a new approach to the creation of visual taxonomies and ontologies of shapes and structures more suitable than classical ontologies to handle the types of graphical and volume components that appear in structures such as proteins, viruses, and nanoparticles

2. research techniques for pattern recognition of nanoparticles and their automatic classification.

At this time, we have already implemented a prototype of a recognition system that can automatically identify specific shapes of nanoparticles in two dimensions. Further research will be needed to create a system that identifies the three-dimensional shapes of nanoparticles that can be used in practice.

In this regard, future applications might include the Material Genome Initiative (see the Appendix) or other projects involving information derived from both ligand and structural macromolecular databases. ${ }^{124}$ These applications might include models that could account for the different conformations of ligands and macromolecules in various physiological environments.

Ontologies or extensions of current terminologies (eg, Medical Subject Headings [MeSH]) can help to annotate or organize papers and experiments - as is done in the -omics area. For instance, papers can be better indexed in PubMed, improving search and access to the nano bibliography. Similarly, databases can be more effectively organized and curated. In this context, research on automated methods to create inventories of informatics resources in the nano areas can be beneficial, as we have shown previously in the bioinformatics area. ${ }^{105}$ Such nanoinformatics approaches can then facilitate access to different types of information and help growth within the field.

\section{Conclusion}

Nanomedicine raises numerous challenges ${ }^{19,125}$ and requires significant investment in informatics to accelerate current research and developments. Such informatics requirements are related to what biomedical informaticians have already carried out in post-genomic research projects, which have transformed biomedical research. For nanotechnology, additional requirements are needed to accommodate the use of computational models and simulations, their range of validity, and increased sharing of codes, to rationally assimilate models from different disciplines and areas of research. In addition, nanoinformatics still needs a common agreement on the goals, subfields, research topics, training needs, and ethical requirements, which could lead to more specific agendas for research and development.

In this review, we have endeavored to illustrate illustrated major challenges and opportunities that research on nanoinformatics faces in advancing nanomedicine. Without such informatics methods and tools, developments will surely lag. In addition, Table 2 and Figure 3 show a timetable of the main events that have taken place in the area of nanoinformatics over the last few years. They show a slow but continuous development, with significant achievements, including conferences, white papers, journal publications, and events.

In this paper we have also illustrated the needs of nanomedicine, in terms of data and information management. We have also discussed some of the problems that nanoinformaticians face with examples of key areas related to current research projects carried out by the authors, showing the kinds of problems and approaches that can be adopted in nanoinformatics. Finally, the potential impact of nanoinformatics has been explored from economic, scientific, and ethical perspectives, emphasizing the opportunities that international collaboration can provide to advance the field. 


\section{Acknowledgments}

The work of the authors in this area of research has been partially funded by the European Commission (the ACTION-Grid Support Action, FP7-224176), and the INBIOMEDvision (Coordination and Support Action, FP7270107), the Spanish Ministry of Economy and Competitiveness (FIS/AES PS09/00069, RETICS COMBIOMED RD07/0067/0006, Ibero-NBIC CYTED 209RT0366), the Consejo Social of the Universidad Politécnica de Madrid, the Comunidad de Madrid and the National Center for Research Resources/National Center for Advancing Translational Sciences (Public Health Services research grants UL1-RR025764 and UL1RR025764-02S2). This project has also been funded in part with federal funds from the National Cancer Institute, National Institutes of Health, under contract HHSN261200800001E. The content of this publication does not necessarily reflect the views or policies of the Department of Health and Human Services, nor does mention of trade names, commercial products, or organizations imply endorsement by the U.S. Government.

\section{Disclosure}

Other than the funding outlined in the Acknowledgments, the authors declare no conflicts of interest in this work.

\section{References}

1. Blum BI, Duncan K, eds. A History of Medical Informatics. New York, NY: ACM Press; Reading, MA: Addison-Wesley; 1990.

2. Ledley RS, Lusted LB. Reasoning foundations of medical diagnosis; symbolic logic, probability, and value theory aid our understanding of how physicians reason. Science. 1959;130(3366):9-21.

3. Kay L. Who Wrote the Book of Life? A History of the Genetic Code. Palo Alto, CA: Stanford University Press; 2000.

4. Collins FS, Morgan M, Patrinos A. The Human Genome Project: lessons from large-scale biology. Science. 2003;300(5617):286-290.

5. Gene Ontology Consortium. Creating the gene ontology resource: design and implementation. Genome Res. 2001;11(8):1425-1433.

6. Kulikowski CA. The micro-macro spectrum of medical informatics challenges: from molecular medicine to transforming health care in a globalizing society. Methods Inf Med. 2002;41(1):20-24.

7. Kohane IS. Bioinformatics and clinical informatics: the imperative to collaborate. J Am Med Inform Assoc. 2000;7(5):512-516.

8. Maojo V, Kulikowski CA. Bioinformatics and medical informatics: collaborations on the road to genomic medicine? J Am Med Inform Assoc. 2003;10(6):515-522.

9. Galperin MY, Fernández-Suárez XM. The 2012 Nucleic Acids Research Database Issue and the online Molecular Biology Database Collection. Nucleic Acids Res. 2012;40(Database issue):D1-D8.

10. Brooksbank C, Cameron G, Thornton J. The European Bioinformatics Institute's data resources. Nucleic Acids Res. 2010;38(Database issue): D17-D25.

11. Wu C, Orozco C, Boyer J, et aI. BioGPS: an extensible and customizable portal for querying and organizing gene annotation resources. Genome Biol. 2009;10(11):R130.

12. Flicek P, Amode MR, Barrell D, et al. Ensembl 2012. Nucleic Acids Res. 2012;40(Database issue):D84-D90.
13. Maglott D, Ostell J, Pruitt KD, Tatusova T. Entrez Gene: gene-centered information at NCBI. Nucleic Acids Res. 2011;39(Database issue): D52-D57.

14. Li Z, Liu X, Wen J, et al. DRUMS: a human disease related unique gene mutation search engine. Hum Mutat. 2011;32(10): E2259-E2265.

15. Schriml LM, Arze C, Nadendla S, et al. Disease Ontology: a backbone for disease semantic integration. Nucleic Acids Res. 2012;40(Database issue):D940-D946.

16. Jonquet C, Shah NH, Musen MA. The open biomedical annotator. Summit on Translat Bioinforma. 2009;2009:56-60.

17. Courtot M, Juty N, Knüpfer C, et al. Controlled vocabularies and semantics in systems biology. Mol Syst Biol. 2011;7:543.

18. Schofield PN, Hancock JM. Integration of global resources for human genetic variation and disease. Hum Mutat. 2012;33(5):813-816.

19. Kim BY, Rutka JT, Chan WC. Nanomedicine. $N$ Engl J Med. 2010;363(25):2434-2443.

20. Freitas RA Jr. Nanomedicine, Volume I: Basic Capabilities. Georgetown, TX: Landes Bioscience; 1999. Available from: http://www.nanomedicine. com/NMI.htm. Accessed February 28, 2012.

21. Jain KK. A Handbook of Nanomedicine. Totowa, NJ: Humana/Springer; 2008.

22. Liu C, Zhang N. Nanoparticles in gene therapy principles, prospects, and challenges. Prog Mol Biol Transl Sci. 2011;104:509-562.

23. Bellare JR. Nanotechnology and nanomedicine for healthcare: challenges in translating innovations from bench to bedside. J Biomed Nanotechnol. 2011;7(1):36-37.

24. Maojo V, Martin-Sanchez F, Kulikowski C, Rodriguez-Paton A, Fritts M. Nanoinformatics and DNA-based computing: catalyzing nanomedicine. Pediatr Res. 2010;67(5):481-489.

25. Workshop on Nanoinformatics Strategies. 2007 June 12-13, Arlington, VA, USA. National Science Foundation - National Nanomanufacturing Network; nd. Available from: http://semanticommunity.info/@api/deki/ files/1347/=Purpose.pdf. Accessed February 28, 2012.

26. Lymberis A. Converging micro-nano-bio technologies towards integrated biomedical systems: state of the art and future perspectives under the EU-information and communication technologies program. Conf Proc IEEE Eng Med Biol Soc. 2008;2008:6-8.

27. Stone AJ, editor. The Theory of Intermolecular Forces. Oxford University Press; Oxford, England. 1996.

28. Zhou C, Yu J, Qin Y, Zheng J. Grain size effects in polycrystalline gold nanoparticles. Nanoscale. 2012. (Epub ahead of print).

29. Oezaslan M, Heggen M, Strasser P. Size-dependent morphology of dealloyed bimetallic catalysts: linking the nano to the macro scale. J Am Chem Soc. 2012;134(1):514-524.

30. Teli MK, Mutalik S, Rajanikant GK. Nanotechnology and nanomedicine: going small means aiming big. Curr Pharm Des. 2010; 16(16):1882-1892.

31. Ma X, Zhao Y, Liang XJ. Theranostic nanoparticles engineered for clinic and pharmaceutics. Acc Chem Res. 2011;44(10):1114-1122.

32. Youns M, Hoheisel JD, Efferth T. Therapeutic and diagnostic applications of nanoparticles. Curr Drug Targets. 2011;12(3):357-365.

33. Bharali DJ, Khalil M, Gurbuz M, Simone TM, Mousa SA. Nanoparticles and cancer therapy: a concise review with emphasis on dendrimers. Int J Nanomedicine. 2009;4:1-7.

34. Harper S, Usenko C, Hutchison JE, Maddux BL, Tanguay RL. In vivo biodistribution and toxicity depends on nanomaterial composition, size, surface functionalisation and route of exposure. J Exp Nanosci. 2008;3(3):195-206.

35. Ruggiero C, Pastorino L, Herrera OL. Nanotechnology based targeted drug delivery. Conf Proc IEEE Eng Med Biol Soc. 2010;2010: 3731-3732.

36. Graham LM, Nguyen TM, Lee SB. Nanodetoxification: emerging role of nanomaterials in drug intoxication treatment. Nanomedicine (Lond). 2011;6(5):921-928.

37. Phan JH, Moffitt RA, Stokes TH, et al. Convergence of biomarkers, bioinformatics and nanotechnology for individualized cancer treatment. Trends Biotechnol. 2009;27(6):350-358. 
38. Liu Y, Miyoshi H, Nakamura M. Nanomedicine for drug delivery and imaging: a promising avenue for cancer therapy and diagnosis using targeted functional nanoparticles. Int J Cancer. 2007;120(12): 2527-2537.

39. Ptak K, Farrell D, Panaro NJ, Grodzinski P, Barker AD. The NCI Alliance for Nanotechnology in Cancer: achievement and path forward. Wiley Interdiscip Rev Nanomed Nanobiotechnol. 2010;2(5): 450-460.

40. Vélez JM, Vélez JJ. The eminent need for an academic program in universities to teach nanomedicine. Int J Nanomedicine. 2011; 6:1733-1738.

41. Maojo V, García-Remesal M, de la Iglesia D, et al. Nanoinformatics: developing advanced informatics applications for nanomedicine. In Prokop A, editor. Intracellular Delivery. Fundamental Biomedical Technologies, 5: Fundamentals and Applications. Dordrecht, Heidelberg, London, New York, NY: Springer; 2011;847-860.

42. Xia XR, Monteiro-Riviere NA, Riviere JE. An index for characterization of nanomaterials in biological systems. Nat Nanotechnol. 2010;5(9):671-675.

43. Dufès C, Uchegbu IF, Schätzlein AG. Dendrimers in gene delivery. Adv Drug Deliv Rev. 2005;57(15):2177-2202.

44. Dobson J. Gene therapy progress and prospects: magnetic nanoparticlebased gene delivery. Gene Ther. 2006;13(4):283-287.

45. De Jong WH, Borm PJ. Drug delivery and nanoparticles: applications and hazards. Int J Nanomedicine. 2008;3(2):133-149.

46. Daum N, Tscheka C, Neumeyer A, Schneider M. Novel approaches for drug delivery systems in nanomedicine: effects of particle design and shape. Wiley Interdiscip Rev Nanomed Nanobiotechnol. 2012;4(1):52-65.

47. Wu Z, Chen K, Yildiz I, et al. Development of viral nanoparticles for efficient intracellular delivery. Nanoscale. 2012:4,3567-3576.

48. Herper M. The truly staggering cost of inventing new drugs. Forbes February 2, 2012. Available from: http://www.forbes.com/sites/ matthewherper/2012/02/10/the-truly-staggeringcost-of-inventing-newdrugs/. Accessed April 28, 2012.

49. Iglesias J. nab-Paclitaxel (Abraxane(R)): an albumin-bound cytotoxic exploiting natural delivery mechanisms into tumors. Breast Cancer Res. 2009;11 Suppl 1:S21.

50. Luo C, Wang Y, Chen Q, et al. Advances of Paclitaxel formulations based on nanosystem delivery technology. Mini Rev Med Chem. 2012;12(5):434-444.

51. Suri SS, Fenniri H, Singh B. Nanotechnology-based drug delivery systems. J Occup Med Toxicol. 2007;2:16.

52. Phillips MA, Gran ML, Peppas NA. Targeted nanodelivery of drugs and diagnostics. Nano Today. 2010;5(2):143-159.

53. Majoros IJ, Thomas TP, Mehta CB, Baker JR Jr. Poly(amidoamine) dendrimer-based multifunctional engineered nanodevice for cancer therapy. J Med Chem. 2005;48(19):5892-5899.

54. Park JH, von Maltzahn G, Ong LL, et al. Cooperative nanoparticles for tumor detection and photothermally triggered drug delivery. $A d v$ Mater. 2010;22(8):880-885.

55. Huynh L, Neale C, Pomès R, Allen C. Computational approaches to the rational design of nanoemulsions, polymeric micelles, and dendrimers for drug delivery. Nanomedicine. 2012;8(1):20-36.

56. Shaw SY, Westly EC, Pittet MJ, Subramanian A, Schreiber SL, Weissleder R. Perturbational profiling of nanomaterial biologic activity. Proc Natl Acad Sci U S A. 2008;105(21):7387-7392.

57. Elbaz J, Willner I. DNA origami: nanorobots grab cellular control. Nat Mater. 2012;11(4):276-277.

58. Douglas SM, Bachelet I, Church GM. A logic-gated nanorobot for targeted transport of molecular payloads. Science. 2012;335(6070):831-834

59. Kostarelos K. Nanorobots for medicine: how close are we? Nanomedicine (Lond). 2010;5(3):341-342.

60. Pautler M, Brenner S. Nanomedicine: promises and challenges for the future of public health. Int J Nanomedicine. 2010;5:803-809.

61. Murthy SK. Nanoparticles in modern medicine: state of the art and future challenges. Int J Nanomedicine. 2007;2(2):129-141.

62. Anguita A, Martín L, Crespo J, Tsiknakis M. An ontology-based method to solve query identifier heterogeneity in post-genomic clinical trials. Stud Health Technol Inform. 2008;136:3-8.
63. Barton J, O Mathúna SC, O’Reilly S, et al. Micro and nano technology enabling ambient intelligence for P-Health. Stud Health Technol Inform. 2005;117:89-97.

64. Nel AE, Mädler L, Velegol D, et al. Understanding biophysicochemical interactions at the nano-bio interface. Nat Mater. 2009;8(7):543-557.

65. Laurencin C, Nair LS. Nanotechnology and Tissue Engineering: The Scaffold. Boca Raton, FL: CRC Press; 2008.

66. Harper SL, Dahl JL, Maddux BL, Tanguay RL, Hutchison JE. Proactively designing nanomaterials to enhance performance and minimize hazard. Int J Nanotechnol. 2008;5(1):124-142.

67. Nyström AM, Fadeel B. Safety assessment of nanomaterials: Implications for nanomedicine. J Control Release. 2012. (Epub ahead of print).

68. Puzyn T, Leszczynska D, Leszczynski J. Toward the development of "nanoQSARs": advances and challenges. Small. 2009;5(22): 2494-2509.

69. Harper SL, Carriere JL, Miller JM, Hutchison JE, Maddux BL, Tanguay RL. Systematic evaluation of nanomaterial toxicity: utility of standardized materials and rapid assays. ACS Nano. 2011;5(6): 4688-4697.

70. Thomas DG, Klaessig F, Harper SL, et al. Informatics and standards for nanomedicine technology. Wiley Interdiscip Rev Nanomed Nanobiotechnol. 2011. (Epub ahead of print).

71. Ostraat ML. The Nanomaterial Registry [presentation]. Research Triangle Park, NC: RTI International; 2011. Available from: http:// www.toxicology.org/isot/ss/nano/docs/Ostraat_guest_presentation.pdf. Accessed April 30, 2012.

72. Kulikowski CA, Kulikowski CW. Biomedical and health informatics in translational medicine. Methods Inf Med. 2009;48(1):4-10.

73. Lavik E, von Recum $H$. The role of nanomaterials in translational medicine. ACS Nano. 2011;5(5):3419-3424.

74. Kuiken T. Nanomedicine and ethics: is there anything new or unique? Wiley Interdiscip Rev Nanomed Nanobiotechnol. 2011;3:111-118.

75. Sandler R. Nanomedicine and nanomedical ethics. Am J Bioeth. 2009;9(10):16-17.

76. Ruping K, Sherman BW. Nanoinformatics: emerging computational tools in nano-scale research. In: Commercial tools, processes and materials, Technical Proceedings of the 2004 NSTI Nanotechnology Conference and Trade Show, Volume 3. Austin, TX: Nano Science and Technology Institute; 525-528. Available from: http://www.nsti.org/ procs/Nanotech2004v3/11/X33.06. Accessed April 30, 2012.

77. De Rosnay J. From molecular biology to biotics: the development of bio-, info- and nano-technologies. Cell Mol Biol (Noisy-le-grand). 2001;47(8):1261-1268.

78. President's Council of Advisors on Science and Technology. Report to the President and Congress on the Third Assessment of the National Nanotechnology Initiative. Washington DC: Executive Office of the President, President's Council of Advisors on Science and Technology; 2010. Available from: http://www.whitehouse.gov/sites/default/files/ microsites/ostp/pcast-nni-report.pdf. Accessed April 30, 2012.

79. De la Iglesia D, Harper S, Hoover MD, et al. Nanoinformatics 2020 Roadmap. Amherst, MA: National Nanomanufacturing Network; 2011. Available from: http://eprints.internano.org/607/1/Roadmap_ FINAL041311.pdf. Accessed February 28, 2012.

80. ACTION-Grid Consortium. The ACTION-Grid White Paper: Linking Biomedical Informatics, Grid Computing and Nanomedicine. ACTIONGrid Consortium; 2010. Available from: http://www.action-grid. eu/documents/ACTION-Grid\%20White\%20Paper.pdf. Accessed February 28, 2012.

81. National Research Council of the National Academies Committee to Develop a Research Strategy for Environmental, Health, and Safety Aspects of Engineered Nanomaterials. A Research Strategy for Environmental, Health, and Safety Aspects of Engineered Nanomaterials. Washington DC: National Academies Press; 2012.

82. Ho D, Garcia D, Ho CM. Nanomanufacturing and characterization modalities for bio-nano-informatics systems. J Nanosci Nanotechnol. 2006;6(4):875-891.

83. Baker NA, Fritts M, Guccione S, et al; National Cancer Institute, caBIG $^{\circledR}$ Integrative Cancer Research Nanotechnology Working Group. Nanotechnology Informatics White Paper. Bethesda, MD: US National Institutes of Health; 2009. 
84. Bizer C. The emerging web of linked data. IEEE Intell Syst. 2009; 24(5):87-92.

85. Renear AH, Palmer CL. Strategic reading, ontologies, and the future of scientific publishing. Science. 2009;325(5942):828-832.

86. Spasic I, Ananiadou S, McNaught J, Kumar A. Text mining and ontologies in biomedicine: making sense of raw text. Brief Bioinform. 2005;6(3):239-251.

87. Gordon N, Sagman U. Nanomedicine Taxonomy [briefing paper]. Ottawa: Canadian Institute of Health Research and Canadian NanoBusiness Alliance; 2003.

88. Thomas DG, Pappu RV, Baker NA. NanoParticle Ontology for cancer nanotechnology research. J Biomed Inform. 2011;44(1): 59-74.

89. Alonso-Calvo R, Maojo V, Billhardt H, Martin-Sanchez F, GarcíaRemesal M, Pérez-Rey D. An agent- and ontology-based system for integrating public gene, protein, and disease databases. $J$ Biomed Inform. 2007;40(1):17-29.

90. McCusker JP, Phillips JA, González Beltrán A, Finkelstein A, Krauthammer M. Semantic web data warehousing for caGrid. $B M C$ Bioinformatics. 2009;10 Suppl 10:S2.

91. Stokes TH, Phan J, Quo CF, Nie S, Wang MD. Bio-nano-informatics: an integrated information management system for personalized oncology. Conf Proc IEEE Eng Med Biol Soc. 2006;1: 3325-3328.

92. Papagiannaros A, Levchenko T, Hartner W, Mongayt D, Torchilin V. Quantum dots encapsulated in phospholipid micelles for imaging and quantification of tumors in the near-infrared region. Nanomedicine. 2009;5(2):216-224.

93. Gao X, Yang L, Petros JA, Marshall FF, Simons JW, Nie S. In vivo molecular and cellular imaging with quantum dots. Curr Opin Biotechnol. 2005;16(1):63-72.

94. Baker JR Jr. The need to pursue and publish clinical trials in nanomedicine. Wiley Interdiscip Rev Nanomed Nanobiotechnol. 2011;3(4):341-342.

95. Lanza GM, Yu X, Winter PM, et al. Targeted antiproliferative drug delivery to vascular smooth muscle cells with a magnetic resonance imaging nanoparticle contrast agent: implications for rational therapy of restenosis. Circulation. 2002;106(22):2842-2847.

96. Chrastina A, Schnitzer JE. Iodine-125 radiolabeling of silver nanoparticles for in vivo SPECT imaging. Int J Nanomedicine. 2010; 5:653-659.

97. Reuveni T, Motiei M, Romman Z, Popovtzer A, Popovtzer R. Targeted gold nanoparticles enable molecular $\mathrm{CT}$ imaging of cancer: an in vivo study. Int J Nanomedicine. 2011;6:2859-2864.

98. Sperling RA, Gil PR, Zhang F, Zanella M, Parak WJ. Biological applications of gold nanoparticles. Chem Soc Rev. 2008;37: 1896-1908.

99. Vargas K, Driscoll J. Computational Nanoscience: Applications for Molecules, Clusters, and Solids. Cambridge: Cambridge University Press; 2011.

100. Archakov AI, Ivanov YD. Analytical nanobiotechnology for medicine diagnostics. Mol Biosyst. 2007;3(5):336-342.

101. Bewick S, Yang R, Zhang M. Complex mathematical models of biology at the nanoscale. Wiley Interdiscip Rev Nanomed Nanobiotechnol. 2009;1(6):650-659.

102. Jaramillo-Botero A, Abrol R, van Duin A, Goddard WA III. Multiscale-multiparadigm modeling and simulation of nanometer scale systems and processes for nanomedical applications. In: Zhang M, Xi N, editors. Nanomedicine: A Systems Engineering Approach. Singapore: Pan Stanford Publishing; 2009:245-300.

103. Chaimovich A, Shell MS. Coarse-graining errors and numerical optimization using a relative entropy framework. J Chem Phys. 2011; 134(9):094112.

104. Cachau RE, Gonzalez-IbanezAM, Gonzalez-Nilo FD. The collaboratory for structural nanobiology. Nanotech. 2010;3:238-241.
105. de la Calle G, García-Remesal M, Chiesa S, de la Iglesia D, Maojo V. BIRI: a new approach for automatically discovering and indexing available public bioinformatics resources from the literature. $B M C$ Bioinformatics. 2009;10:320.

106. García-Remesal M, Cuevas A, Pérez-Rey D, et al. PubDNA Finder: a web database linking full-text articles to sequences of nucleic acids. Bioinformatics. 2010;26(21):2801-2802.

107. García-Remesal M, Maojo V, Crespo J, Billhardt H. Logical schema acquisition from text-based sources for structured and non-structured biomedical sources integration. AMIA Anпu Symp Proc. 2007; 2007:259-263

108. Ai J, Biazar E, Jafarpour M, et al. Nanotoxicology and nanoparticle safety in biomedical designs. Int J Nanomedicine. 2011;6: $1117-1127$.

109. Webster TJ. NanoTox: hysteria or scientific studies? Int $J$ Nanomedicine. 2008;3(2):i-ii.

110. Lai DY. Toward toxicity testing of nanomaterials in the 21st century: a paradigm for moving forward. Wiley Interdiscip Rev Nanomed Nanobiotechnol. 2012;4(1):1-15.

111. Adiseshaiah PP, Hall JB, McNeil SE. Nanomaterial standards for efficacy and toxicity assessment. Wiley Interdiscip Rev Nanomed Nanobiotechnol. 2010;2(1):99-112.

112. Oberdörster G, Oberdörster E, Oberdörster J. Concepts of nanoparticle dose metric and response metric. Environ Health Perspect. 2007; 115(6):A290.

113. Hussain S, Vanoirbeek JA, Hoet PH. Interactions of nanomaterials with the immune system. Wiley Interdiscip Rev Nanomed Nanobiotechnol. 2012;4(2):169-183.

114. ISA Commons. What is the ISA framework? In: ISA Commons [homepage on the Internet]. 2011. Available from: http://isacommons. org/. Accessed April 30, 2012.

115. Minimum Information for Nanomaterial Characterization (MINChar) Initiative. Characterization Matters [homepage on the Internet]. 2008. Available from: http://characterizationmatters.org/. Accessed February 28, 2011.

116. Aillon KL, Xie YM, El-Gendy N, Berkland CJ, Forrest ML. Effects of nanomaterial physicochemical properties on in vivo toxicity. $A d v$ Drug Delivery Rev. 2009;61(6):457-466.

117. Peng RD. Reproducible research in computational science. Science. 2011;334(6060):1226-1227.

118. Hasman A, Ammenwerth E, Dickhaus H, et al. Biomedical informatics - a confluence of disciplines? Methods Inf Med. 2011;50(6): 508-524.

119. Kjølberg KL, Strand R. Conversations about responsible nanoresearch. Nanoethics. 2011;5(1):99-113.

120. Sandhiya S, Dkhar SA, Surendiran A. Emerging trends of nanomedicine - an overview. Fundam Clin Pharmacol. 2009;23(3): 263-269.

121. Rosse C, Mejino JL Jr. A reference ontology for biomedical informatics: the Foundational Model of Anatomy. J Biomed Inform. 2003;36(6):478-500.

122. Garten Y, Altman RB. Pharmspresso: a text mining tool for extraction of pharmacogenomics concepts and relationships from full text. $B M C$ Bioinformatics. 2009;10 Suppl 2:S6.

123. Maojo V, Crespo J, García-Remesal M, de la Iglesia D, Perez-Rey D, Kulikowski C. Biomedical ontologies: toward scientific debate. Methods Inf Med. 2011;50(3):203-216.

124. Ito JI, Tabei Y, Shimizu K, Tomii K, Tsuda K. PDB-scale analysis of known and putative ligand-binding sites with structural sketches. Proteins. 2012;80(3):747-763.

125. Riehemann K, Schneider SW, Luger TA, Godin B, Ferrari M, Fuchs H. Nanomedicine - challenge and perspectives. Angew Chem Int Ed Engl. 2009;48(5):872-897. 


\section{Appendix}

This appendix presents a very large table listing the large number of initiatives and databases spanning the collecting, gathering, curating, and providing of nano-related information for professionals and other nanotechnology users.

Table AI Summary of current nanoinformatics initiatives and projects

\begin{tabular}{|c|c|c|c|c|}
\hline Name/acronym & Description & Institution & Geographical area & Start year \\
\hline \multicolumn{5}{|c|}{ Initiatives and scientific networks } \\
\hline $\begin{array}{l}\text { Nano Science and Technology } \\
\text { Institute (NSTI) }\end{array}$ & $\begin{array}{l}\text { It integrates nano and other } \\
\text { technologies through education, } \\
\text { conventions, business publishing, } \\
\text { and research services }\end{array}$ & NSTI & USA & 1997 \\
\hline NanoBioTechnology Center & $\begin{array}{l}\text { Experts on nanobiotechnology: } \\
\text { biomolecular devices, cellular } \\
\text { microdynamics, cell-surface } \\
\text { interactions, cell biology, etc }\end{array}$ & National Science Foundation (NSF) & USA & 2000 \\
\hline $\begin{array}{l}\text { National Nanotechnology } \\
\text { Initiative (NNI) }\end{array}$ & $\begin{array}{l}\text { Central point of communication, } \\
\text { cooperation, and collaboration for } \\
\text { all US federal agencies engaged in } \\
\text { nanotechnology research }\end{array}$ & 25 US governmental agencies & USA & 2000 \\
\hline $\begin{array}{l}\text { Global Nanotechnology } \\
\text { Network }\end{array}$ & $\begin{array}{l}\text { Platform for addressing shared } \\
\text { global challenges through nanoscale } \\
\text { science, engineering, development, } \\
\text { and education }\end{array}$ & $\begin{array}{l}\text { Diverse nanotechnology stakeholders } \\
\text { from industry, academia, and } \\
\text { government }\end{array}$ & International & 2001 \\
\hline $\begin{array}{l}\text { International Council on } \\
\text { Nanotechnology (ICON) }\end{array}$ & $\begin{array}{l}\text { Portal for information about the } \\
\text { environmental, health, and safety } \\
\text { aspects of nanotechnology }\end{array}$ & Rice University & USA & 2004 \\
\hline $\begin{array}{l}\text { National Cancer Institute }(\mathrm{NCl}) \\
\text { Alliance for nanotechnology } \\
\text { in Cancer }\end{array}$ & $\begin{array}{l}\text { Committed to build a community } \\
\text { of researchers dedicated to using } \\
\text { nanotechnology to advance the } \\
\text { fight against cancer }\end{array}$ & $\begin{array}{l}\mathrm{NCl} \text {, US National Institutes } \\
\text { of Health }(\mathrm{NIH})\end{array}$ & USA & 2004 \\
\hline Alliance for NanoHealth & $\begin{array}{l}\text { Promotes nano-based approaches, } \\
\text { nano-resources, and tools to } \\
\text { battle against cancer, heart } \\
\text { diseases, or diabetes }\end{array}$ & $\begin{array}{l}\text { Texas Medical Center } \\
\text { (Houston, TX) }\end{array}$ & USA & 2005 \\
\hline $\begin{array}{l}\text { European Technology Platform } \\
\text { on Nanomedicine }\end{array}$ & $\begin{array}{l}\text { Led by industry together with the } \\
\text { European Commission (EC) for } \\
\text { the application of nanotechnology } \\
\text { in health care }\end{array}$ & EC & Europe & 2005 \\
\hline Nanoforum & $\begin{array}{l}\text { European Nanotechnology } \\
\text { Gateway }\end{array}$ & $\begin{array}{l}\text { Former Fifth RTD Framework } \\
\text { Programme, now an European } \\
\text { Economic Interest Group }\end{array}$ & Europe & 2005 \\
\hline $\begin{array}{l}\text { Nanomedicine Roadmap } \\
\text { Initiative }\end{array}$ & $\begin{array}{l}\text { Nanomachinery of the cell to } \\
\text { control and manipulate molecules } \\
\text { and supramolecular assemblies } \\
\text { in living cells }\end{array}$ & US NIH & USA & 2005 \\
\hline $\begin{array}{l}\text { Nanotechnology } \\
\text { Characterization Laboratory }\end{array}$ & $\begin{array}{l}\text { A NCl-supported lab to perform } \\
\text { and standardize nanomaterials } \\
\text { intended for cancer therapeutics } \\
\text { and diagnostics }\end{array}$ & $\mathrm{NCl}$, US NIH & USA & 2005 \\
\hline $\begin{array}{l}\text { Nanotechnologies } \\
\text { Industries Association }\end{array}$ & $\begin{array}{l}\text { It represents the industries' views, } \\
\text { interfaces with governments, } \\
\text { consultation on regulation, } \\
\text { standards, media and public }\end{array}$ & $\begin{array}{l}\text { Group of companies from a } \\
\text { variety of industry sectors }\end{array}$ & International & 2005 \\
\hline $\begin{array}{l}\text { Project on Emerging } \\
\text { Nanotechnologies }\end{array}$ & $\begin{array}{l}\text { Designed to minimize potential } \\
\text { risks to health and environment, } \\
\text { identifying gaps in knowledge } \\
\text { and regulatory processes }\end{array}$ & $\begin{array}{l}\text { Pew Charitable Trusts, Woodrow } \\
\text { Wilson International Center for } \\
\text { Scholars }\end{array}$ & USA & 2005 \\
\hline
\end{tabular}


Table A I (Continued)

\begin{tabular}{|c|c|c|c|c|}
\hline Name/acronym & Description & Institution & Geographical area & Start year \\
\hline $\begin{array}{l}\text { Safer Nanomaterials and } \\
\text { Nanomanufacturing Initiative }\end{array}$ & $\begin{array}{l}\text { New nanomaterials and } \\
\text { nanomanufacturing approaches that } \\
\text { offer a high level of performance, } \\
\text { yet pose minimal harm }\end{array}$ & $\begin{array}{l}\text { Universities of Oregon, Pacific } \\
\text { Northwest Lab, Oregon Nanoscience } \\
\text { and Mircrotechnologies Institute }\end{array}$ & USA & 2005 \\
\hline $\begin{array}{l}\text { Nanosciences, Nanotechnologies, } \\
\text { Materials and new Production } \\
\text { Technologies Programme }\end{array}$ & $\begin{array}{l}\text { EC program which funds research, } \\
\text { development, demonstration, } \\
\text { and coordination projects }\end{array}$ & EC under FP7 & Europe & 2006 \\
\hline $\begin{array}{l}\text { National Institute for } \\
\text { Nanotechnology }\end{array}$ & $\begin{array}{l}\text { Integrated, multidisciplinary, } \\
\text { involves researchers in physics, } \\
\text { chemistry, engineering, biology, } \\
\text { informatics, and medicine }\end{array}$ & $\begin{array}{l}\text { National Research Council of } \\
\text { Canada and the University } \\
\text { of Alberta }\end{array}$ & Canada & 2006 \\
\hline $\begin{array}{l}\text { National Network of } \\
\text { Nanomedicine Development } \\
\text { Centers }\end{array}$ & $\begin{array}{l}\text { Initiative to determine the } \\
\text { physical properties of cellular } \\
\text { and subcellular components }\end{array}$ & US NIH & USA & 2006 \\
\hline SAFENANO & $\begin{array}{l}\text { Europe's center of excellence on } \\
\text { nanotechnology hazard and risk, } \\
\text { facilitating responsible development } \\
\text { of safe nanomaterials }\end{array}$ & $\begin{array}{l}\text { Institute of Occupational } \\
\text { Medicine (IOM) }\end{array}$ & Europe & 2006 \\
\hline $\begin{array}{l}\text { Technology cooperative } \\
\text { framework on nanoscale } \\
\text { analytical and measurement } \\
\text { methods }\end{array}$ & $\begin{array}{l}\text { Initiative for interlaboratory } \\
\text { comparison on nanoparticle } \\
\text { size. Characterization among ten } \\
\text { laboratories from six member } \\
\text { economies }\end{array}$ & $\begin{array}{l}\text { Asia-Pacific Economy Cooperation } \\
\text { Industrial Science and Technology } \\
\text { Working Group }\end{array}$ & $\begin{array}{l}\text { International } \\
\text { (Asia-Pacific) }\end{array}$ & 2005 \\
\hline ACTION-Grid & $\begin{array}{l}\text { International project on health care } \\
\text { and nanoinformatics between Latin } \\
\text { America, the Western Balkans, and } \\
\text { the European Union (EU) }\end{array}$ & EC under FP7 & $\begin{array}{l}\text { EU. Africa, USA, } \\
\text { Latin America }\end{array}$ & 2008 \\
\hline $\begin{array}{l}\text { European Foundation for } \\
\text { Clinical Nanomedicine }\end{array}$ & $\begin{array}{l}\text { Initiative for prevention, diagnosis, } \\
\text { and therapy through nanomedicine } \\
\text { as well as exploration of } \\
\text { its implications }\end{array}$ & $\begin{array}{l}\text { Nonprofit institution, with } \\
\text { researchers from the EU and USA }\end{array}$ & USA & 2008 \\
\hline ICPCNanoNet & $\begin{array}{l}\text { Collaboration between } \\
\text { organizations and scientists in the } \\
\text { EU and International Cooperation } \\
\text { Partner Countries (ICPC) }\end{array}$ & EC under FP7 & $\begin{array}{l}\text { EU and partner } \\
\text { countries }\end{array}$ & 2008 \\
\hline $\begin{array}{l}\text { Institute of Electrical and } \\
\text { Electronics Engineers (IEEE) } \\
\text { Nanotechnology Council }\end{array}$ & IEEE group on nanotechnology & IEEE & International & 2008 \\
\hline $\begin{array}{l}\text { International Alliance for } \\
\text { NanoEHS Harmonization }\end{array}$ & $\begin{array}{l}\text { Scientists from the EU, Japan, and } \\
\text { the USA to establish reproducible } \\
\text { approaches for dealing with } \\
\text { nanoparticle hazards }\end{array}$ & $\begin{array}{l}\text { Peer-group of scientists that } \\
\text { voluntarily collaborate }\end{array}$ & $\begin{array}{l}\text { International } \\
\text { (Europe, Japan, } \\
\text { and the USA) }\end{array}$ & 2008 \\
\hline NanoPediatrics Program & $\begin{array}{l}\text { Focused on the development and } \\
\text { use of nanomedicine for the care } \\
\text { of children }\end{array}$ & $\begin{array}{l}\text { Mattel Children's Hospital, University } \\
\text { of California Los Angeles, CA }\end{array}$ & USA & 2008 \\
\hline $\begin{array}{l}\text { National Nanomanufacturing } \\
\text { Network }\end{array}$ & $\begin{array}{l}\text { Alliance of academic, government, } \\
\text { and industry partners to promote } \\
\text { nanomanufacturing workshops and } \\
\text { exchanges }\end{array}$ & NSF & USA & 2008 \\
\hline $\begin{array}{l}\text { Cancer Biomedical Informatics } \\
\left.\text { Grid (caBIG }{ }^{\circledR}\right) \text { Nanotechnology } \\
\text { Working Group }\end{array}$ & $\begin{array}{l}\text { Rational design of nanomaterials } \\
\text { and discovering nanoparticle } \\
\text { toxicity; development of standards } \\
\text { and ontologies }\end{array}$ & $\mathrm{NCl}$, US NIH & USA & 2009 \\
\hline EU Nanosafety Cluster & $\begin{array}{l}\text { EC's initiative to maximize } \\
\text { synergies between the Sixth } \\
\text { Framework Programme (FP6) and } \\
\text { Seventh Framework Programme } \\
\text { (FP7) projects, addressing nanosafety }\end{array}$ & Compendium of EC-funded projects & Europe & 2009 \\
\hline
\end{tabular}


Table AI (Continued)

\begin{tabular}{|c|c|c|c|c|}
\hline Name/acronym & Description & Institution & Geographical area & Start year \\
\hline $\begin{array}{l}\text { Ibero-American Network of } \\
\text { Convergent Technologies for } \\
\text { Health }\end{array}$ & $\begin{array}{l}\text { Research on the social impact of } \\
\text { converging technologies } \\
\text { (Nano-Bio-Info-Cogno) in } \\
\text { lbero-America }\end{array}$ & $\begin{array}{l}\text { Latin-American Science and } \\
\text { Technology Development Programme }\end{array}$ & $\begin{array}{l}\text { Latin America, } \\
\text { Spain, and Portugal }\end{array}$ & 2009 \\
\hline NanoCom & $\begin{array}{l}\text { To bridge the gap between } \\
\text { laboratory-based and industrial } \\
\text { applications in nanotechnology }\end{array}$ & $\begin{array}{l}\text { EC through FP7. Coordinator: } \\
\text { University of Nottingham }\end{array}$ & Europe & 2009 \\
\hline $\begin{array}{l}\text { Nanotechnology Informatics } \\
\text { White Paper }\end{array}$ & $\begin{array}{l}\text { White paper covering the } \\
\text { history of nanotechnology } \\
\text { and the application of } \\
\text { nanotechnology in the } \\
\text { biomedical field }\end{array}$ & $\begin{array}{l}\text { National Characterization } \\
\text { Laboratory, US NCI }\end{array}$ & USA & 2009 \\
\hline ObservatoryNano & $\begin{array}{l}\text { European observatory for } \\
\text { science-based and economic expert } \\
\text { analysis of nanotechnologies, }\end{array}$ & $\begin{array}{l}\text { EC-FP7. Coordinator: Institute } \\
\text { of Nanotechnology, UK }\end{array}$ & Europe & 2009 \\
\hline MINAM 2.0 & $\begin{array}{l}\text { Brings together micro- and } \\
\text { nano-related organizations }\end{array}$ & $\begin{array}{l}\text { EC-FP7. Coordinator: Karlsruher } \\
\text { Institut Für Technologie }\end{array}$ & Europe & 2010 \\
\hline NanoGEM & $\begin{array}{l}\text { Evaluates the hazards of industrially } \\
\text { relevant nanomaterials and } \\
\text { nanoparticles contained in } \\
\text { processed products }\end{array}$ & $\begin{array}{l}\text { Institute of Energy and } \\
\text { Environmental Technology }\end{array}$ & Germany & 2010 \\
\hline ProNano & $\begin{array}{l}\text { Coaching services to research } \\
\text { institutions or persons interested } \\
\text { in the commercial exploitation of } \\
\text { nanotechnologies }\end{array}$ & $\begin{array}{l}\text { EC-FP7. Coordinator: Zabala } \\
\text { Innovation Consulting, SA }\end{array}$ & Europe & 2010 \\
\hline $\begin{array}{l}\text { University of California Center } \\
\text { for Environmental Implications } \\
\text { of Nanotechnology }\end{array}$ & $\begin{array}{l}\text { Development of environmental } \\
\text { decision-making tools for managing } \\
\text { engineered nanomaterials across a } \\
\text { wide spectrum of nano/bio } \\
\text { interfaces in cells, bacteria, etc }\end{array}$ & $\begin{array}{l}\text { NSF, Environmental Protection } \\
\text { Agency, California NanoSystems } \\
\text { Institute, University of California }\end{array}$ & USA & 2010 \\
\hline Materials Genome Initiative & $\begin{array}{l}\text { To develop an infrastructure to } \\
\text { accelerate advanced materials } \\
\text { discovery and deployment in the } \\
\text { United States }\end{array}$ & $\begin{array}{l}\text { National Science and } \\
\text { Technology Council }\end{array}$ & USA & 2011 \\
\hline $\begin{array}{l}\text { Technology Platform } \\
\text { NanoFutures }\end{array}$ & $\begin{array}{l}\text { A European Technology Integrating } \\
\text { and Innovation Platform, } \\
\text { multi-sectorial }\end{array}$ & EC & Europe & 2011 \\
\hline Euro-Nano-Tox & $\begin{array}{l}\text { Portal for researchers and industry } \\
\text { seeking critical toxicological data } \\
\text { for nano-structured materials }\end{array}$ & $\begin{array}{l}\text { BioNanoNet Forschungsgesellschaft } \\
\mathrm{mbH}\end{array}$ & Austria & 2011 \\
\hline \multicolumn{5}{|l|}{ Data repositories and standards } \\
\hline $\begin{array}{l}\text { ICON Environmental, Health } \\
\text { and Safety Database }\end{array}$ & $\begin{array}{l}\text { Contains summaries (abstracts) } \\
\text { and citations }\end{array}$ & Rice University, ICON & USA & 2004 \\
\hline $\begin{array}{l}\text { Molecular Imaging and Contrast } \\
\text { Agent Database (MICAD) }\end{array}$ & $\begin{array}{l}\text { Online source of scientific } \\
\text { information regarding molecular } \\
\text { imaging and contrast agents }\end{array}$ & NCBI, US NIH & USA & 2004 \\
\hline Nanotechnology Standards Panel & $\begin{array}{l}\text { Development of standards } \\
\text { in nanotechnology including } \\
\text { nomenclature/terminology; } \\
\text { materials properties and testing }\end{array}$ & $\begin{array}{l}\text { American National } \\
\text { Standards Institute }\end{array}$ & USA & 2004 \\
\hline ISO TC 229 & $\begin{array}{l}\text { Developing standards for the } \\
\text { understanding and control of matter } \\
\text { and processes at the nanoscale to } \\
\text { create improved materials }\end{array}$ & $\begin{array}{l}\text { International Association for } \\
\text { Standardization (ISO) }\end{array}$ & International & 2005 \\
\hline $\begin{array}{l}\text { National Toxicology } \\
\text { Program Database }\end{array}$ & $\begin{array}{l}\text { Toxicology information about } \\
\text { chemicals and nanoscale materials, } \\
\text { abstracts, reports, and data from } \\
\text { toxicology studies }\end{array}$ & $\begin{array}{l}\text { NIH, National Institute for } \\
\text { Occupational Safety and Health } \\
\text { (NIOSH), US Food and Drug } \\
\text { Administration }\end{array}$ & USA & 2005 \\
\hline
\end{tabular}


Table Al (Continued)

\begin{tabular}{|c|c|c|c|c|}
\hline Name/acronym & Description & Institution & Geographical area & Start year \\
\hline $\begin{array}{l}\text { American Society for Testing } \\
\text { and Materials (ASTM) } \\
\text { Nanotechnology }\end{array}$ & $\begin{array}{l}\text { ASTM standards for nanotechnology } \\
\text { as well as nanotechnology } \\
\text { terminology, property testing, } \\
\text { and issues of health and safety }\end{array}$ & ASTM & USA & 2006 \\
\hline caNanoLab Database & $\begin{array}{l}\text { Annotation of nanomaterials with } \\
\text { characterizations resulting from } \\
\text { physico-chemical and in vitro assays }\end{array}$ & $\mathrm{NCl}$, US NIH & USA & 2006 \\
\hline SAFENANO Database & $\begin{array}{l}\text { Data resource on nanotechnology } \\
\text { hazard and risk }\end{array}$ & IOM & UK & 2006 \\
\hline $\begin{array}{l}\text { Organisation for Economic } \\
\text { Co-operation and Development } \\
\text { (OECD) Database on Research } \\
\text { into Safety of Manufactured } \\
\text { Nanomaterials }\end{array}$ & $\begin{array}{l}\text { Collects research projects that } \\
\text { address environmental, human } \\
\text { health, and safety issues of } \\
\text { manufactured nanomaterials }\end{array}$ & OECD & International & 2007 \\
\hline $\begin{array}{l}\text { British Standards Institute (BSI) } \\
\text { Nanotechnology }\end{array}$ & $\begin{array}{l}\text { Documents relevant to } \\
\text { nanotechnology, addressing } \\
\text { nanotechnology terminology, } \\
\text { health and safety issues, and } \\
\text { product labeling }\end{array}$ & BSI & UK & 2008 \\
\hline $\begin{array}{l}\text { Collaboratory for Structural } \\
\text { Nanobiology }\end{array}$ & $\begin{array}{l}\text { Nanoparticle structure files and } \\
\text { related research data, as well as } \\
\text { resources for the visualization of } \\
\text { nanoparticles }\end{array}$ & $\begin{array}{l}\mathrm{NCl} \text {, US NIH, Universidad de } \\
\text { Talca (Chile) }\end{array}$ & USA, Latin America & 2008 \\
\hline ISO Nano Terminology & $\begin{array}{l}\text { It lists unambiguous terms and } \\
\text { definitions related to particles } \\
\text { in the field of nanotechnologies }\end{array}$ & ISO & International & 2008 \\
\hline MINChar & $\begin{array}{l}\text { A community initiative to improve } \\
\text { the utility of nanotoxicology } \\
\text { studies through effective } \\
\text { nanomaterial characterization }\end{array}$ & $\begin{array}{l}\text { The Dow Chemical Company, Evonik } \\
\text { Industries, Rice University, ICON, } \\
\text { BASF Corporation, NIOSH, Clemson } \\
\text { University, Woodrow Wilson } \\
\text { International Center for Scholars, } \\
\text { National Institute of Environmental } \\
\text { Health Sciences (NIEHS), DuPont }\end{array}$ & USA & 2008 \\
\hline NanoParticle Ontology & $\begin{array}{l}\text { An ontology with basic physical, } \\
\text { chemical and functional nano } \\
\text { characteristics, as used in cancer } \\
\text { diagnosis and therapy }\end{array}$ & $\mathrm{caBIG}$ & USA & 2008 \\
\hline $\begin{array}{l}\text { Cancer Open Biomedical } \\
\text { Resource Project }\end{array}$ & $\begin{array}{l}\text { Toolset for information retrieval } \\
\text { for cancer nanotechnology-related } \\
\text { information using biomedical } \\
\text { ontologies }\end{array}$ & $\begin{array}{l}\text { National Center for Biomedical } \\
\text { Ontology through US NIH (NIH) }\end{array}$ & USA & 2009 \\
\hline Nanomaterials Registry & $\begin{array}{l}\text { Public resource of curated } \\
\text { information on biological and } \\
\text { environmental interactions of } \\
\text { nanomaterials }\end{array}$ & NIBIB, NIEHS, NCl & USA & 2009 \\
\hline $\begin{array}{l}\text { Nanoparticle Information } \\
\text { Library }\end{array}$ & $\begin{array}{l}\text { Nanoparticle library to organize } \\
\text { and share information on } \\
\text { nanomaterials, including health } \\
\text { and safety-associated properties }\end{array}$ & $\mathrm{NIOSH}$ & USA & 2009 \\
\hline Nano-TAB & $\begin{array}{l}\text { Data-sharing challenges in } \\
\text { nanotechnology by identifying } \\
\text { nanomaterials and characterizations } \\
\text { in a tab-delimited format }\end{array}$ & $\mathrm{NCl}$, US NIH & USA & 2009 \\
\hline $\mathrm{DaNa}$ & $\begin{array}{l}\text { Acquisition, evaluation, and } \\
\text { public-oriented presentation } \\
\text { of society-relevant data and } \\
\text { findings relating to nanomaterials }\end{array}$ & DECHEMA eV & Germany & 2010 \\
\hline
\end{tabular}


Table A I (Continued)

\begin{tabular}{|c|c|c|c|c|}
\hline Name/acronym & Description & Institution & Geographical area & Start year \\
\hline $\begin{array}{l}\text { Nanomaterial-Biological } \\
\text { Interactions Knowledgebase }\end{array}$ & $\begin{array}{l}\text { Repository for annotated data } \\
\text { on nanomaterial characterization } \\
\text { synthesis methods and } \\
\text { nanomaterial-biological interactions }\end{array}$ & $\begin{array}{l}\text { Oregon universities and } \\
\text { Microtechnologies Institute }\end{array}$ & USA & 2010 \\
\hline Nano-QSAR & $\begin{array}{l}\text { Initiative for applying structure-- } \\
\text { activity relationships (SARs) to } \\
\text { predict properties of nanomaterials }\end{array}$ & $\mathrm{NCl}$, US NIH & USA & 2010 \\
\hline $\begin{array}{l}\text { European Repository of } \\
\text { Reference Nanomaterials }\end{array}$ & $\begin{array}{l}\text { Nanomaterial repository with a } \\
\text { collection representing } 25 \\
\text { different types of nanomaterials }\end{array}$ & EC's Joint Research Centre & Europe & 2011 \\
\hline $\begin{array}{l}\text { InterNano NanoManufacturing } \\
\text { Taxonomy }\end{array}$ & $\begin{array}{l}\text { Central digital repository of } \\
\text { nanomanufacturing research and } \\
\text { trade information for the } \\
\text { nanomanufacturing community }\end{array}$ & $\begin{array}{l}\text { Coordinated by the National } \\
\text { Nanomanufacturing Network }\end{array}$ & USA & 2011 \\
\hline $\begin{array}{l}\text { ISA-TAB-Nano } \\
\text { (ASTM WK28974) }\end{array}$ & $\begin{array}{l}\text { Standard format for representing } \\
\text { information on nanomaterials and } \\
\text { small molecules along with their } \\
\text { assay characterization data }\end{array}$ & $\mathrm{NCl}$, US NIH & USA & 2012 \\
\hline \multicolumn{5}{|l|}{ Collaborative platforms } \\
\hline $\begin{array}{l}\text { Network for Computational } \\
\text { Nanotechnology (NCN) }\end{array}$ & $\begin{array}{l}\text { Cyber-resource for } \\
\text { nanotechnology theory, } \\
\text { modeling, and simulation }\end{array}$ & NSF & USA & 2002 \\
\hline Nano Network & $\begin{array}{l}\text { Consortium of resources } \\
\text { available to companies }\end{array}$ & ONAMI & USA & 2003 \\
\hline caNanoLab & $\begin{array}{l}\text { Data-sharing portal designed to } \\
\text { facilitate information sharing in } \\
\text { the biomedical nanotechnology } \\
\text { research community }\end{array}$ & $\mathrm{NCl}$, US NIH & USA & 2006 \\
\hline InterNano & $\begin{array}{l}\text { Information clearinghouse for the } \\
\text { nanomanufacturing community }\end{array}$ & $\begin{array}{l}\text { Coordinated by the National } \\
\text { Nanomanufacturing Network } \\
\text { and funded by the NSF }\end{array}$ & USA & 2007 \\
\hline NANOSAFE Inc & $\begin{array}{l}\text { An extensive network of experts } \\
\text { in the fields of nanoscience } \\
\text { and engineering, industrial and } \\
\text { environmental health and safety, } \\
\text { toxicology, and risk assessment }\end{array}$ & $\begin{array}{l}\text { Virginia Tech Corporate Research } \\
\text { Center's KnowledgeWorks Business } \\
\text { Accelerator }\end{array}$ & USA & 2007 \\
\hline GoodNanoGuide & $\begin{array}{l}\text { Collaboration platform designed } \\
\text { to enhance the ability of experts } \\
\text { to exchange ideas on how best } \\
\text { to handle nanomaterials }\end{array}$ & Rice University & USA & 2009 \\
\hline NanoHub - NCN & $\begin{array}{l}\text { Framework with a set of tools } \\
\text { for online simulation and more } \\
\text { for nanotechnology }\end{array}$ & NSF & USA & 2009 \\
\hline QNano & $\begin{array}{l}\text { EU-funded infrastructure for } \\
\text { nanomaterial safety testing }\end{array}$ & EC through FP7 & Europe & 2011 \\
\hline \multicolumn{5}{|c|}{ Dissemination and information portals } \\
\hline Nano Tech Wire & Latest nanotechnology news & $\begin{array}{l}\text { NNI, NSTI, FEI Company, } \\
\text { Veeco, Zyvex }\end{array}$ & USA & 2003 \\
\hline ICON nanoEHS Virtual Journal & $\begin{array}{l}\text { The Virtual Journal of } \\
\text { Nanotechnology Environment, } \\
\text { Health and Safety }\end{array}$ & Rice University, ICON (ICON) & USA & 2004 \\
\hline NanoWerk & $\begin{array}{l}\text { Committed to educating, informing, } \\
\text { and inspiring people about } \\
\text { nanosciences and nanotechnologies }\end{array}$ & NanoWerk LLC & USA & 2005 \\
\hline $\begin{array}{l}\text { PEN Environmental, Health } \\
\text { and Safety Inventory }\end{array}$ & $\begin{array}{l}\text { An inventory of current research } \\
\text { involving nanotechnology health } \\
\text { and environmental implications }\end{array}$ & $\begin{array}{l}\text { Pew Charitable Trusts, Woodrow } \\
\text { Wilson International Center for } \\
\text { Scholars }\end{array}$ & USA & 2005 \\
\hline
\end{tabular}


Table A I (Continued)

\begin{tabular}{|c|c|c|c|c|}
\hline Name/acronym & Description & Institution & Geographical area & Start year \\
\hline $\begin{array}{l}\text { PEN Nanotechnology } \\
\text { Medical Applications }\end{array}$ & $\begin{array}{l}\text { Web-based resource to better } \\
\text { understand current and future } \\
\text { applications of nanotechnology } \\
\text { in various fields of medicine }\end{array}$ & $\begin{array}{l}\text { Pew Charitable Trusts, Woodrow } \\
\text { Wilson International Center for } \\
\text { Scholars }\end{array}$ & USA & 2005 \\
\hline TryNano & $\begin{array}{l}\text { Information resource for anyone } \\
\text { interested in learning about } \\
\text { nanoscience and nanotechnology, } \\
\text { oriented to the general public }\end{array}$ & $\begin{array}{l}\text { IBM, IEEE, New York Hall } \\
\text { of Science }\end{array}$ & International & 2007 \\
\hline $\begin{array}{l}\text { Nanotechnology Risk } \\
\text { Resources }\end{array}$ & $\begin{array}{l}\text { References to papers, articles, } \\
\text { and books on (or related to) } \\
\text { potential health and environmental } \\
\text { risks of nanomaterials }\end{array}$ & $\begin{array}{l}\text { Nanotechnology Citizens } \\
\text { Engagement Organization }\end{array}$ & USA & 2010 \\
\hline $\begin{array}{l}\text { National Institute of Standards } \\
\text { and Technology (NIST) } \\
\text { Nanotechnology Portal }\end{array}$ & $\begin{array}{l}\text { Portal about nanotechnology- } \\
\text { related research conducted in } \\
\text { NIST's laboratories that develops } \\
\text { measurements and standards }\end{array}$ & NIST & USA & 2010 \\
\hline
\end{tabular}

\section{Publish your work in this journal}

The International Journal of Nanomedicine is an international, peerreviewed journal focusing on the application of nanotechnology in diagnostics, therapeutics, and drug delivery systems throughout the biomedical field. This journal is indexed on PubMed Central, MedLine, CAS, SciSearch $\AA$, Current Contents ${ }^{\circledR} /$ Clinical Medicine,
Journal Citation Reports/Science Edition, EMBase, Scopus and the Elsevier Bibliographic databases. The manuscript management system is completely online and includes a very quick and fair peer-review system, which is all easy to use. Visit http://www.dovepress.com/ testimonials.php to read real quotes from published authors. 